\title{
3 \\ Linkages between \\ Environmental Policy and Competitiveness
}

\section{OECD Environment Working Papers No. 13}

OECD 
Organisation de Coopération et de Développement Économiques

Organisation for Economic Co-operation and Development

11-Jan-2010

ENVIRONMENT DIRECTORATE

English - Or. English

ENVIRONMENT WORKING PAPER No.13

LINKAGES BETWEEN ENVIRONMENTAL POLICY AND COMPETITIVENESS

By Leena Lankoski (1)

(1) Department of Economics and Management, University of Helsinki, Finland

JEL classification: O31, O33, O38

Keywords: eco-innovation, competitiveness, environment policy, resource efficiency, globalization, supply chain, Porter hypothesis, pollution haven

All Environment Working Papers are available at www.oecd.org/env/workingpapers 


\section{OECD ENVIRONMENT WORKING PAPERS}

This series is designed to make available to a wider readership selected studies on environmental issues prepared for use within the OECD. Authorship is usually collective, but principal authors are named.

The papers are generally available only in their original language English or French with a summary in the other if available.

The opinions expressed in these papers are the sole responsibility of the author(s) and do not necessarily reflect those of the OECD or the governments of its member countries.

Comment on the series is welcome, and should be sent to either env.contact@oecd.org or the Environment Directorate, 2, rue André Pascal, 75775 PARIS CEDEX 16, France.

OECD Environment Working Papers are published on www.oecd.org/env/workingpapers

Applications for permission to reproduce or translate all or part of this material should be made to: OECD Publishing, rights@oecd.org or by fax 33145249930.

Copyright OECD 2009 


\begin{abstract}
Debates exist between those who claim that environmental policy will impose additional burdens and costs on industries, thus impairing their competitiveness, and those who claim that improved environmental performance can spur competitiveness. These arguments often surface when new environmental policy regulation are considered, e.g. when the REACH Directive was introduced in Europe, or when a government is considering the introduction of a carbon tax.

The report develops a conceptual framework to shed some light on this difficult debate. Competitiveness impacts of environmental policies may derive from the policy itself, or from the improvements of the environmental performance that derives from the policy. These impacts can be analysed at either firm or industry levels; they may differ over the short and long term. Globalisation, with the increasing role of MNEs and mobile capital and labour, is adding more complexity.

This framework is used to decipher some of the messages that come out of empirical studies on these issues. Empirical evidence is mixed, and the paper identifies methodological and substantive reasons why empirical research fails to determine the relationship between environmental policy and competitiveness.

Lessons derive from this literature review. Typically, even when implementing the environmental policy is clearly in the overall interest of society, the costs and benefits of the policy are unlikely to be equally shared among economic agents. While some win, individual firms or industries may stand to lose. Policy design should make sure that the adverse competitiveness impacts are not unnecessarily large, for example by paying attention to predictability, transition periods, and transaction costs. Specific measures to support the losers in their adjustment can also be developed. Sometimes measures to mitigate the adverse competitiveness impacts of an environmental policy are necessary to achieve political support for the policy. In those instances, the planned measures should be carefully analysed from several angles to ensure that they do not inadvertently hurt the efficiency and effectiveness of the original policy.
\end{abstract}

More work is required to further explore these issues, which are consequential for the design, the implementation and the enforcement of environmental policies.

JEL classification: $\mathrm{O} 31, \mathrm{O} 33, \mathrm{O} 38$

Keywords: eco-innovation, competitiveness, environment policy, resource efficiency, globalization, supply chain, Porter hypothesis 


\section{RÉSUMÉ}

Il y a souvent débat entre ceux qui pensent que les politiques environnementales vont imposer des charges supplémentaires aux entreprises et ainsi détériorer leur compétitivité, et d'autres qui pensent qu'une meilleure performance environnementale est un facteur de compétitivité. Ces débats affleurent en particulier quand de nouvelles réglementations environnementales sont débattues, par exemple lorsque la directive REACH a été mise en œuvre en Europe, ou quand des gouvernements réfléchissent à l'introduction d'une taxe carbone.

Dans ce rapport, un cadre conceptuel est proposé, pour tirer des enseignements de ces débats. Les impacts d'une politique environnementale sur la compétitivité peuvent découler de la politique ellemême, ou des conséquences de la politique sur les performances environnementales. Ces impacts se mesurent au niveau des firmes ou des secteurs économiques; ils peuvent être différents à court ou à long terme. La globalisation rend ces mécanismes encore plus complexes, avec le rôle accru des multinationales et la mobilité du capital et de l'emploi.

Le cadre conceptuel est utilisé pour donner un sens aux résultats des études empiriques sur ces thèmes. Ces résultats sont ambigus et le rapport propose des raisons à la fois méthodologiques et de fond qui expliquent pourquoi les recherches empiriques ne parviennent pas à comprendre la relation entre les politiques environnementales et la compétitivité.

L'analyse des sources documentaires fait ressortir quelques messages. Par exemple, même quand une politique environnementale a des effets positifs clairs sur l'ensemble de la collectivité, il est probable que les coûts et les bénéfices de cette politique soient inégalement répartis entre les agents économiques. Il se peut que certaines entreprises ou certains secteurs gagnent alors que d'autres perdent. La politique doit être conçue de sorte que les coûts ne soient pas indûment élevés, par exemple en annonçant à l'avance, en prévoyant des périodes de transition, et en étant attentifs aux coûts de transaction. Il est possible de prévoir des mesures dédiées aux perdants afin d'accompagner leurs ajustements. Dans certains cas, des mesures qui limitent les impacts négatifs d'une politique sur la compétitivité sont utiles pour susciter une adhésion à cette politique. Dans ces cas, les mesures envisagées doivent être analysées sous différents angles pour s'assurer qu'elles ne restreignent pas l'efficacité et l'efficience du projet initial.

Des travaux complémentaires sont nécessaires pour étudier ces sujets qui sont importants pour la conception, la mise en œuvre et le respect des politiques environnementales.

Classification JEL : O31, O33, O38

Mots clé : éco-innovation, compétitivité, politique de l'environnement, efficacité en ressources, mondialisation, circuits d'approvisionnement, hypothèse de Porter 


\section{FOREWORD}

One of the challenges environment ministries face is to make globalisation and environment performance compatible and mutually supportive. The issue of the potential impact of environmental policies on competitiveness comes to the forefront of the political agenda, as is illustrated by the debates linked with the REACH Directive in Europe or with the negotiations of a post-Kyoto framework to mitigate climate change.

The OECD Programme of work on Environment includes work to better design environmental policies so as to achieve environmental policy objectives effectively and efficiently while minimising any potential impacts on competitiveness and, where possible, boosting it.

This paper was developed in the context of the 2008 meeting of the OECD Environment Policy Committee at Ministerial level. Its objective is to cover recent conceptual developments on the environmental policy - competitiveness linkages as well as to review empirical research literature. The paper revisits a stock-taking study of the topic carried out by the OECD in $1997^{1}$. It proposes policy conclusions addressed to governments.

The paper was developed by Dr. Leena Lankoski, University of Helsinki, Department of Economics and Management. Earlier drafts have been reviewed by the OECD Working Party on Global and Structural Policies.

\footnotetext{
${ }^{1}$ Adams, J. 1997. Environmental policy and competitiveness in a globalised economy: Conceptual issues and a review of the empirical evidence. In: Globalisation and environment: Preliminary perspectives. Paris: OECD.
} 


\section{TABLE OF CONTENTS}

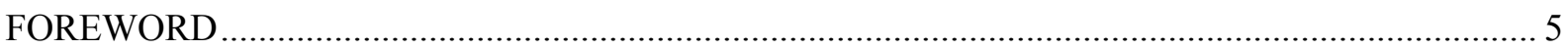

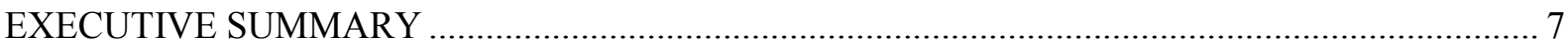

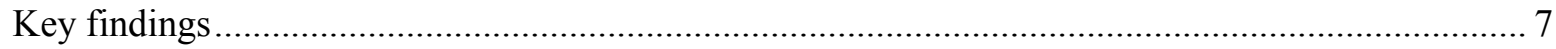

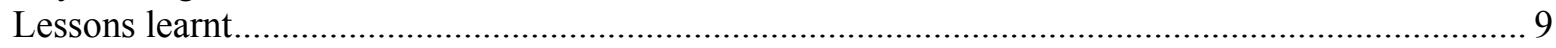

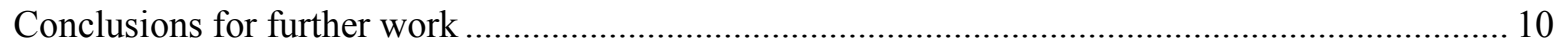

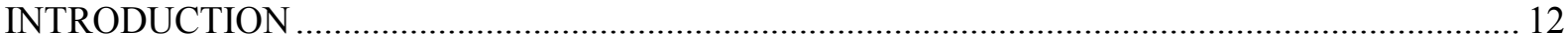

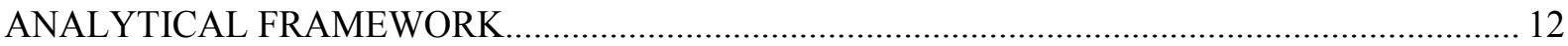

Environmental policy - environmental performance - competitiveness triangle at the firm level..... 15

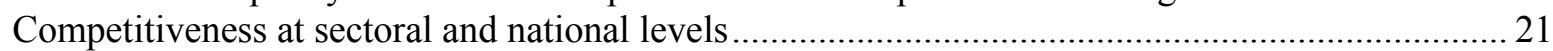

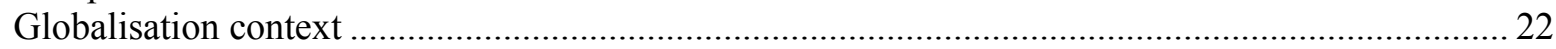

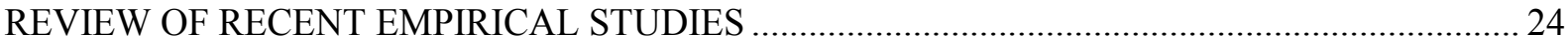

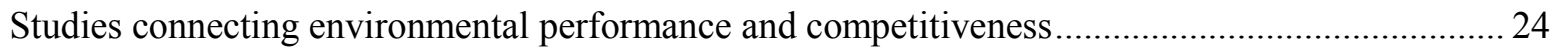

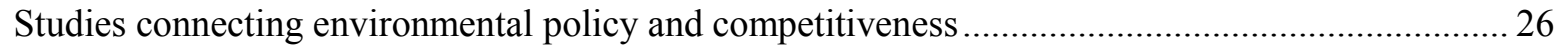

Forecasts and simulations of competitiveness impacts of environmental policies ............................. 30

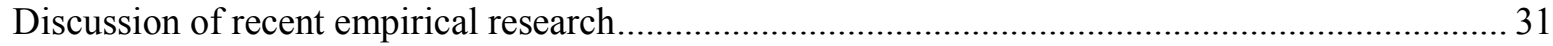

REVIEW OF PROS AND CONS OF MEASURES PROPOSED TO ADDRESS ADVERSE

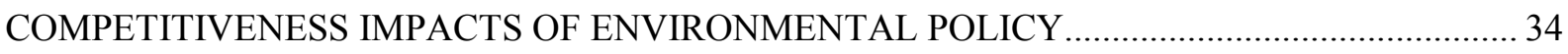

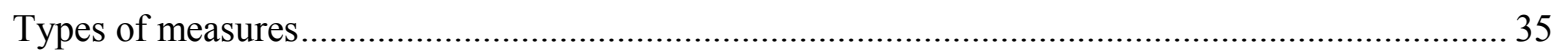

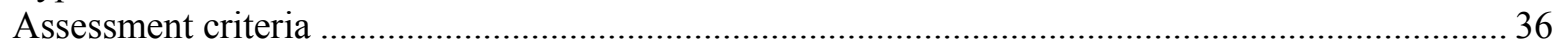

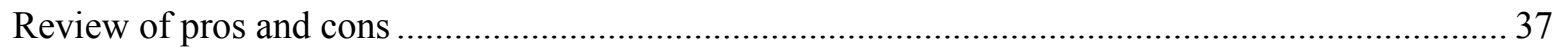

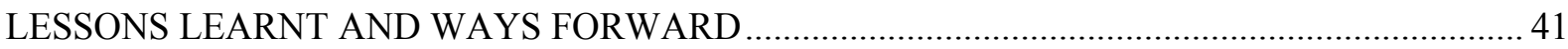

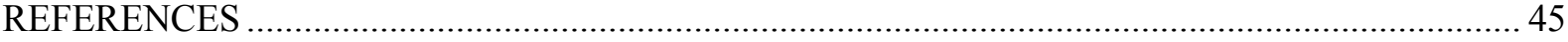

\section{Figures}

Figure 1. Analytical framework on the linkages between environmental policy and competitiveness examined in the study.

Figure 2. Mechanisms from firm-level environmental performance to firm-level economic performance.

Figure 3. Direct mechanisms from environmental policy to firm-level economic

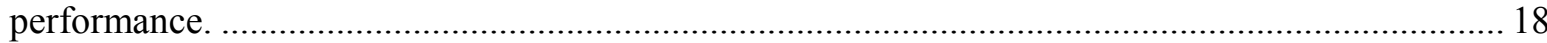

Figure 4. The build-up of national competitiveness (see Porter et al., 2007) ................................. 21 


\section{EXECUTIVE SUMMARY}

\section{Key findings}

Environmental policy may force environmental performance improvements on a firm, and thus in effect impose on it the competitiveness impacts associated with those improvements. Improving environmental performance may produce positive competitiveness impacts through (1) improved resource efficiency; (2) improved stakeholder relations; (3) product differentiation; (4) improved market access; and (5) the creation of new business. It may result in negative competitiveness impacts through (1) increases in production costs; (2) reduced productivity; and (3) adverse impacts on perceived product quality.

Environmental policy may also have competitiveness impacts that arise directly from the policy itself rather than from environmental performance improvements by the firm. Environmental policy may produce such positive competitiveness impacts through (1) creating demand for the firm's output; (2) raising rivals' costs; and (3) improving environmental quality. It may result in negative competitiveness impacts through (1) reducing demand for the firm's output; (2) increasing input prices; (3) imposing transaction costs; (4) imposing new cost elements on a firm; and (5) adversely affecting productivity.

At industry level, the competitiveness of firms that operate within a given industry is examined from an aggregate perspective. Since firms within the same industry can differ from one another in terms of their inputs, strategies, technologies, resources, and so on, the competitiveness impacts of environmental policy can vary between different firms in a given sector. If the differences between firms are significant, the various firm-level mechanisms presented above can produce for some firms a net competitiveness impact that is positive, while for some other firms this net impact can be negative.

Thus, there are several potential concurrent channels through which an environmental policy measure can affect competitiveness. The net impact of all the possible positive and negative impacts determines the overall competitiveness impact of an environmental policy measure. The net impact may be different in the short term than in the long term. Further, it has been argued to take the form of a dynamic, case-specific, inverted U-shaped function of environmental performance.

Globalisation can influence the environment - competitiveness relationship in various ways. It can make environmental self-regulation spread through MNE structures and global supply chains. It can also affect the ability of firms to improve their environmental performance as environmental technology, knowledge, and best practices are disseminated through trade and investment linkages. With increased competition, interest groups may feel a more urgent need to oppose any cost-increasing policy proposals, and with mobile production, pressure groups have more leverage on policy. Globalisation also complicates the analysis of competitiveness impacts of environmental policy since with increasingly mobile capital and labour, the two-way link between competitiveness at firm level and national level is broken. Finally, in a globalised economy, stringent environmental requirements may tend to migrate from the strict to the lenient jurisdictions, thus making eventual competitiveness gains from lenient standards temporary only.

A great number of empirical studies have been carried out on the environment - competitiveness relationship. They include firm-level studies that seek to establish a connection between environmental performance and accounting or stock market performance; sectoral and national level studies trying to find a link between the strictness of environmental policies and productivity, 
innovation, trade flows or investment and location decisions; and ex ante studies that attempt to forecast the competitiveness impacts of a specific environmental policy.

In total, the evidence is mixed. There are several reasons why it can be considered that the vast empirical literature has so far failed to settle the issue: (1) The results are not compatible with each other. Different studies yield contradictory findings, and the communication between different strands of research could be stronger. (2) The results are not compatible with theoretical predictions. The theoretical argument that environmental policy hurts competitiveness has not been substantiated empirically. However, as the argument is theoretically persuasive within mainstream economics, researchers keep on attempting to uncover the predicted impacts. (3) The results are not compatible with policy-making practice. Even if the adverse competitiveness impacts have failed to be corroborated, firms typically oppose environmental policy proposals by appealing to a loss of competitiveness.

Those researchers who think that some conclusions can be drawn from the mixed body of evidence connecting environmental performance to competitiveness at the firm level tend to argue that the relationship is slightly positive, or at least not negative. On the other hand, those researchers who think that some pattern does emerge from the recent sectoral and national level studies connecting environmental policy to competitiveness expressed as trade flows and location decisions tend to interpret this relationship as negative.

A multitude of data and methodological problems can be identified to explain the inability of empirical research to conclusively determine the relationship between environmental policy and competitiveness. In addition, there are also possible substantive explanations. One such explanation commonly offered is that environmental costs constitute such a small share of total costs, and differences in policy stringency between trading partners have been so small, that any important competitiveness impacts simply do not exist. Another possibility is that there is some underlying relationship between environmental policy and competitiveness, but this relationship is masked by other, opposing drivers. In particular, endowments with capital, skilled labour, or natural resources may serve to neutralise the impacts of environmental policies.

The view is gaining foothold that the relationship between environmental policy and competitiveness is not universal but contingent: the magnitude and even the direction of competitiveness impacts may differ between different firms and industries, types of policy measures, or environmental issues. Hence, the relationship is easily lost in aggregation. Rather than finding a one-size-fits-all answer, the task is to understand the nature of the impacts in specific circumstances. Indeed, if the relationship follows a dynamic, case-specific inverted $U$, extrapolating findings across different firms and industries, issues, strictness levels or time periods is problematic.

For example, different environmental policy measures may produce a different bundle of individual competitiveness impacts. The choice of policy measures partly determines the extent to which environmental performance improvements are generated in firms, and thus the extent of the resulting competitiveness impacts. In addition, different policy instruments may differ in terms of their demand impacts, cost impacts on the firm and its rivals, as well as on impacts on environmental quality.

Another example of the case-specific nature of the competitiveness impacts relates to industry structure. Firms that sell a homogeneous product in a perfectly competitive market cannot pass on cost increases to product prices but must face reduced profits. By contrast, those firms that have some degree of market power can pass (part of) the cost increase in product prices, which reduces the competitiveness impacts. 
The other side of the two-way linkages between environmental policy and competitiveness deals with the impacts that competitiveness concerns may have on environmental policy-making. Various measures have been proposed to accompany environmental policies with the aim of mitigating eventual adverse competitiveness impacts. Such measures can be divided in three groups: (1) measures to soften competitiveness impacts in regulated countries; (2) measures to promote environmental action in non-regulated countries; and (3) measures to adjust the impacts of environmental policies at the border. However, sometimes expected positive competitiveness impacts can also lead firms to lobby for stricter environmental policies, as well as to take environmental initiatives in advance of governments.

Several perspectives - economic, environmental, legal, and political - need to be employed in order to be able to effectively examine the pros and cons of the various measures to mitigate adverse competitiveness impacts. A message that arises from the discussion of pros and cons of the mitigating measures is that there are no categorical answers. All measures to mitigate adverse competitiveness impacts have positive and negative features, and it depends on the specifics of the environmental problem and the original environmental policy, as well as on the detailed design and implementation of the mitigating measure, how the balance between the pros and cons is struck. This means that the application of mitigating measures requires careful analysis in each situation.

\section{Lessons learnt}

The competitiveness impacts depend on the type of environmental policy measure adopted and the details of its implementation; on firm and sector characteristics; and on the environmental domain. All these contingencies are simultaneously at work. Thus, we can distinguish between three levels of detail in the analysis of competitiveness impacts. At the most general level, the question to be examined is the relationship between environmental policy and competitiveness. As we have seen, there are no unconditional answers to this question. At an intermediate level of detail, what is examined are the competitiveness impacts per policy measure, per sector, or per environmental issue. Examining this question can be expected to produce clearer policy messages. At the most detailed level, the question is about how a specific policy measure targeting a specific environmental issue affects some specific firms or industries. This is the analysis level that can produce the most definitive answers. Which analysis level to choose depends on the objectives of the study to be conducted as well as on practical considerations.

Situations do exist where environmental policy leads to positive competitiveness impacts (socalled win-win situations). However, it is unclear how widespread such win-win situations are and how significant the positive competitiveness impacts can be. Clear policy messages arise with regard to win-win situations. Environmental policy should be instituted for environmental reasons and not in order to pursue win-win situations. Nevertheless, policy should strive to be win-win-compatible; this speaks in favour of policies that provide incentives to innovation, are stable and predictable, make use of suitable transition periods, focus on end results rather than means, and use economic policy instruments. Moreover, any win-win opportunities that exist should be identified and exploited by firms. Here policy can play a role by improving firms' awareness of win-win possibilities and supporting their capacity to implement win-win solutions, for example by spreading information on best practices or promoting the dissemination of environmentally friendly technology.

There can be situations where unjustified or exaggerated concerns about negative competitiveness impacts prevail. Such is the case, for example, when analysis of the competitiveness impacts focuses on cost increases only and ignores possibilities for market benefits and cost savings, or when a static analysis fails to account for dynamic effects such as innovation and technological development and thus leads to an overestimation of costs. On the other hand, there can also be overly 
positive expectations about the win-win potential of an environmental policy measure, for example if the particular characteristics of the policy measure, the sector, and the environmental issue are not recognized. The recommendation in both cases is to obtain better information of the actual competitiveness impacts. When considering the economic impacts, all the different positive and negative channels connecting environmental policy to competitiveness should be duly accounted for, even if the impacts are hard to measure or quantify. The impacts should be analysed with a sufficient level of detail so that the situation-specific impacts can be assessed.

Situations remain where environmental policy will result in negative competitiveness impacts and there is thus a trade-off between environmental and economic objectives. Again, it is not clear how widespread trade-off situations are, and how important the adverse impacts can be. Trade-off situations are the most challenging situations for policy-making, but there are clear policy messages also for these situations. It is necessary for an effective environmental policy to have competitiveness impacts in the sense that sustainable production will become more competitive and unsustainable production less competitive. Further, it is exactly in the trade-off situations that environmental policy is most needed to achieve the environmental objectives; where win-win opportunities are present, more emphasis can be put on voluntary approaches by industry. Environmental policy development in trade-off situations requires that the environmental benefits obtained are weighed against the adverse economic consequences. This is done at the level of the whole society. Because of different preferences, the weighing may result in different outcomes in different societies or at different time periods. The weighing becomes more complicated if the spatial or temporal dispersion of the environmental benefits and of the adverse economic consequences differ from each other.

Even when implementing the environmental policy is clearly in the overall interest of society despite the adverse competitiveness impacts, the costs and benefits of the policy are unlikely to be equally shared among societal actors. While some win, individual firms or industries may stand to lose. Policy design should make sure that the adverse competitiveness impacts are not unnecessarily large, for example by paying attention to predictability, transition periods, and transaction costs. Specific measures to support the losers in their adjustment can also be developed. Sometimes measures to mitigate the adverse competitiveness impacts of an environmental policy are necessary to achieve political support for the policy. In those instances, the planned measures should be carefully analysed from several angles to ensure that they do not inadvertently hurt the efficiency and effectiveness of the original policy.

\section{Conclusions for further work}

Conceptual and empirical analysis indicates that both the competitiveness effects of environmental policies and the appropriateness of various measures to address those competitiveness effects are highly case-specific and depend on the firm or industry, the environmental issue, and the policy measure in question. Thus, rather than from very aggregated and general questions, robust and useful results may be obtained from smaller and more fine-grained questions. This may be a fruitful direction for further work.

It is an important but analytically neglected point that the characteristics of various environmental issues may have a bearing on the competitiveness impacts of environmental policies. Identifying the essential determining characteristics of environmental issues from the perspective of the environmental policy - competitiveness relationship would be needed. Similarly, the consideration of the justification for various mitigating measures can also be different for different environmental issues. 
Much of recent analytical activity is focusing on climate change, but climate change is in many respects different from several other environmental issues as an environmental, economic, and political phenomenon. Engaging in corresponding work on other environmental policies than those related to climate change would thus be welcome. 


\title{
INTRODUCTION
}

The relationship between environmental policy and competitiveness is an important policy topic, the relevance of which is only heightened by the ongoing climate negotiations. The OECD has previously carried out a stock-taking study of the topic (Adams, 1997), and there is a need to update the stock-taking exercise. The objective of this study is to cover recent conceptual developments on the environmental policy - competitiveness linkages as well as to review empirical research literature since 1997. To this end, the paper develops an analytical framework of the linkages between environmental policy and competitiveness and, based on this framework, presents a literature review. The paper does not attempt to conduct new research, nor will it address issues which are not covered by the existing literature.

\begin{abstract}
ANALYTICAL FRAMEWORK
A strong analytical framework is required to be able to credibly examine the linkages between environmental policy and competitiveness, especially as the empirical results are fragmented and indecisive as will be shown later. Current conceptual understanding of the linkages between environmental policy and competitiveness are discussed through an analytical framework presented in Figure 1 . The study addresses the relationships between environmental policy and competitiveness in two directions: how environmental policy affects competitiveness (chapter 3) and how concerns about competitiveness affect environmental policy (chapter 4). The framework takes into account current trends of globalisation and how they potentially impact the competitiveness debate.
\end{abstract}


Figure 1. Analytical framework on the linkages between environmental policy and competitiveness examined in the study.

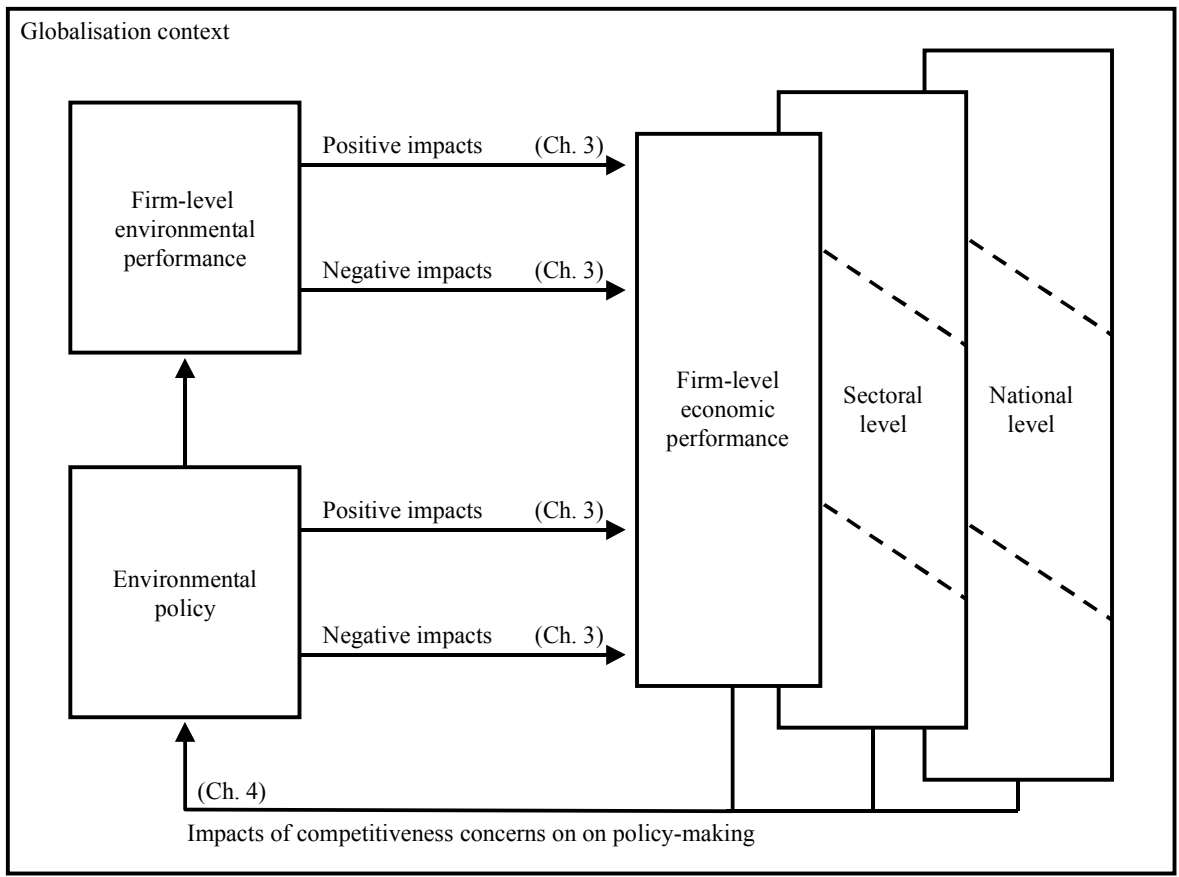

It is a key feature of the analytical framework in this study that the framework makes an explicit distinction between environmental performance (considered in terms of harmful environmental impacts) and environmental policy. To fully understand the competitiveness impacts of environmental policy, it is necessary to understand two different avenues through which they may arise:

- First, implementing a certain environmental performance level may carry competitiveness implications for a firm. For example, reducing energy use may require investment in energyefficient equipment, produce savings in input costs, and result in a favourable image among stakeholders. Environmental policy may force environmental performance improvements on a firm, and thus in effect impose on it the competitiveness impacts associated with those improvements.

- Second, environmental policy may have competitiveness impacts that arise directly from the policy itself rather than from environmental performance improvements by the firm. This is the case when complying with an environmental policy does not change the physical environmental performance level of a firm; for example, when an emissions trading system is established, a firm purchases a sufficient amount of emission allowances and continues to emit at the same level than previously. Or, such impacts are also present in those cases where the environmental performance of the firm is improved, but the competitiveness impacts are different from what they would have been if the firm had made a corresponding environmental performance improvement without the regulation. For example, it is possible that a firm can implement a given environmental performance level more cost-efficiently if the ways and means for this are left for the firm to decide rather than prescribed through a technology standard. 
Thus, even if the interest in this paper is on the impacts of environmental policy on competitiveness, there is also a need to consider the linkages between environmental performance and competitiveness. A certain policy measure may give rise to both impact avenues described above simultaneously, and for both avenues, different positive and negative competitiveness impacts may arise. Thus, there are several potential concurrent channels through which an environmental policy measure can affect competitiveness. The net impact of all these channels determines the overall competitiveness impact on a firm. Distinguishing between the different channels can help obtain a clearer picture of the mechanisms connecting environmental policy to competitiveness.

Another key feature of the framework is that the framework builds understanding of the linkages between environmental policy and competitiveness at the firm level, where the impacts are actually created, and extends this understanding to sectoral and national levels. Because the linkages are complex and difficult to measure, such a bottom-up approach is useful as it allows a more detailed consideration of heterogeneous situations and allows the richness of the linkages to emerge in full. Indeed, it has recently been argued that too little attention has been paid to firm-level contingencies in environmental policy debates (DeCanio, 2008) and that an understanding of firm-level foundations of competitiveness is crucial (Porter et al., 2007).

However, a bottom-up approach is complicated by the fact that companies may extend across several sectors as well as operate in many countries. In a globalised economy, multinational enterprises (MNEs) are important players. Moreover, Krugman (1994) has challenged the usefulness of the concept of national competitiveness entirely. Thus, extending the understanding of firm-level impacts to sectoral or national levels is not mechanistic or straightforward.

A few words are in order about the term competitiveness. The term is broad and vague, and it has been used in different meanings, which may have contributed to a certain lack of progress in the debate. In particular, the meaning of competitiveness at the national level and the relationship of this term to competitiveness at the firm and sectoral level has been problematic. In the environmental policy - competitiveness debate, the implicit meaning of competitiveness at different analysis levels has been as follows (Adams, 1997):

- Competitiveness at the firm level refers to an ability of a firm to sell goods and services in the market and stay in business.

- Competitiveness at the sectoral level refers to the aggregate competitiveness of the firms that operate within a given sector in an economy, compared to international rivals.

- Competitiveness at the national level refers to an ability of a country to increase its economic standard of living.

It is useful to think about competitiveness as an ability. As this ability itself is difficult to gauge, most of the definitions that we encounter in literature and the measures used in empirical studies in fact address determinants of competitiveness (such as productivity) or consequences of competitiveness (such as accounting-based or stock-market-based measures of economic performance at the firm level; volume of activity, market shares, and trade flows at the sectoral level; and trade and investment flows and growth at the national level).

In this study, the word "competitiveness" is used as a convenient shorthand notation, with the understanding that when talking about "competitiveness impacts" of environmental policy, we are referring to the incremental impact of environmental policy on firms' economic performance at the micro level, and on the aggregations and consequences of this effect at the macro level. Identifying the 
"incremental impact" as our target of analysis implies a recognition that environmental policy is but one of many factors potentially influencing competitiveness.

\section{Environmental policy - environmental performance - competitiveness triangle at the firm level}

\section{Mechanisms from environmental performance to economic performance}

Figure 2 illustrates the positive and negative linkages between firm-level environmental and economic performance (see e.g. Jaffe et al., 1995; Ambec \& Lanoie, 2008; Lankoski, 2008a)

Figure 2. Mechanisms from firm-level environmental performance to firm-level economic performance.

\begin{tabular}{|c|c|c|c|}
\hline \multirow{8}{*}{$\begin{array}{l}\text { Firm-level } \\
\text { environmental } \\
\text { performance }\end{array}$} & & Efficiency & \multirow{8}{*}{$\begin{array}{l}\text { Firm-level } \\
\text { economic } \\
\text { performance }\end{array}$} \\
\hline & \multirow[b]{2}{*}{ Positive } & Stakeholder relations & \\
\hline & & Differentiation & \\
\hline & \multirow[b]{4}{*}{ Negative } & Market access & \\
\hline & & New business & \\
\hline & & Production costs & \\
\hline & & Productivity & \\
\hline & & Quality & \\
\hline
\end{tabular}

Five different mechanisms can be distinguished through which positive competitiveness impacts may arise from environmental performance:

- Improving environmental performance may result in improved resource efficiency. Environmental responsibility and efficiency follow a similar logic: pollution and waste represent inefficiency (Porter \& van der Linde, 1995). Improving environmental performance may thus result in direct cost savings as smaller amounts of materials, energy and services are needed to produce the firm's output or environmentally harmful inputs can be replaced with cheaper alternatives. For example, there are tens of descriptions of companies that have been able to simultaneously reduce pollution and the cost of resources, energy, and services (see e.g. Lanoie \& Tanguay, 2000). Both the types of companies and the environmental initiatives undertaken in these examples are very diverse, suggesting that the set of potential opportunities is broad (Ambec \& Lanoie, 2008). In addition to smaller efficiency improvements with existing technology, a need to improve environmental performance may also result in important technological breakthroughs.

- Improving environmental performance may result in improved stakeholder relations, which can produce cost savings in transactions with various stakeholder groups. High environmental performance may translate into an ability to compete for the best employees, and into high employee health and motivation as well as low employee turnover. Lower risks brought by high environmental performance may be reflected in a lower price for capital and insurance. Good relations with local populations and the general public may facilitate the continuation and expansion of the firm's operations. Good relations with authorities and 
compliance with environmental regulations may reduce delays and produce savings in regulatory costs such as taxes, charges, permit costs, liability costs, fines, and litigation costs.

- Improving environmental performance may allow product differentiation. High environmental performance may make the product or service more attractive in the market, and provide more value for the customer, which can increase revenue through a price premium or an increased sales volume. For example, eco-labelling is a tool that can be used to support environmental differentiation, and the sales of products with the European ecolabel increased from $€ 51$ million in 2000 to $€ 644$ million in 2004 (A mbec \& Lanoie, 2008).

- Improving environmental performance may improve market access. High environmental performance may increase revenue as the firm is able to offer its product or service in countries with strict environmental performance standards, or to buyers that follow environmental criteria in their purchasing decisions. Such criteria may originate from the environmental management systems of the buyers or from public purchasing requirements. For example, Ambec \& Lanoie (2008: 48) write that "presumably, all plants with ISO 14001 certification pay attention to their suppliers' environmental performance, as this is one of the criteria to be fulfilled to obtain the certification (Barla, 2007). Furthermore, a recent survey of the OECD, covering more than 4000 facilities in seven countries, showed that $43 \%$ of them assess their suppliers' environmental performance (Johnstone et al., 2007b)."

- Improving environmental performance may contribute to the creation of new business. The firm can start selling to other firms the know-how, technology, or services it has developed to improve its environmental performance. What were previously waste streams may be turned into a new source of income by converting them into inputs for other firms, and selling emission rights can also produce new income. Innovations that lead to entirely new business areas may also result. For example, it is an emerging trend that "those European companies that are well prepared for REACH, e.g. Ciba and BASF create new commercial opportunities through the creation of 'expert services' selling their knowledge and knowhow to others, including non-European firms. Charging other firms for access to toxicological data they possess through REACH registration consortia and other such groups is regarded also by some as an opportunity to offset the costs of REACH at the very minimum." (Lorenz et al., 2008: 23).

Three different mechanisms can be distinguished through which negative competitiveness impacts may arise from environmental performance:

- Improving environmental performance may require increases in direct production costs. In order to achieve a high environmental performance level, capital investments may need to be incurred for machinery, equipment, and buildings. Moreover, operating costs for materials, energy, and labour (including management time) may increase if the new inputs are more expensive or if they are needed in larger quantities. (Jaffe et al., 1995)

- In addition to these direct cost increases, improving environmental performance may reduce productivity in more subtle ways. The new processes and production practices may be less efficient, and the transitional period may involve switching costs, obsolete capital and production disruptions. Environmental investments may crowd out other, more productive 
investments, and scarce resources (time, money, R\&D effort) that are directed to producing environmental quality cannot be used to produce saleable output. (Jaffe et al., 1995)

- Improving environmental performance may adversely affect the perceived quality, e.g. efficiency or appearance, of the firm's product or service, resulting in revenue loss. For example, customers may believe (falsely or not) that organically produced fruit will go bad more quickly than other fruit, or that an environmentally friendly detergent will not remove stains as effectively as other products.

\section{Mechanisms from environmental policy to environmental performance}

Firms' motives for improving environmental performance and the role that environmental policy plays in this context have been discussed from different angles (see also Hilliard, 2004). On the one hand, it has been argued that market-based motivations for environmental performance improvements are more important than environmental policy. For example, in a study based on the OECD survey data from 4000 manufacturing facilities, Henriques and Sadorsky (2007) found that "the general role of public authorities with respect to the decision to improve environmental management is insignificant, with employees, corporate headquarters and downstream buyers being more influential" (Johnstone, 2007, 261), although it should be noted that the adoption of environmental management practices that was examined by Henriques and Sadorsky may not directly equate environmental performance in terms of harmful environmental impacts discussed in this paper. This view suggests an important role for voluntary approaches to environmental performance improvements in firms.

On the other hand, it has been argued that without the external push offered by policy, even profitable opportunities for environmental performance improvements may go ignored in firms (Porter $\&$ van der Linde, 1995). There are a variety of reasons for this, such as lack of information, limited attention and experience, limited capabilities for innovation, and organizational structures, incentive systems and inertia (see e.g. Hilliard, 2004; Porter \& van der Linde, 1995). In addition, not all environmental performance improvements are economically profitable, at least not within the decision-making time frames of most firms. This view suggests that policy is needed to trigger environmental performance improvements in firms. Indeed, in another study based on the abovementioned OECD survey database, Johnstone et al. (2007a) found that perceived policy stringency had a positive and significant impact on environmental performance.

How large environmental performance improvements an environmental policy generates in a firm depends on two factors:

- The strictness of policy. The stricter the policy requirements, the larger the environmental performance improvements that are required for compliance.

- The choice of policy measures. With some environmental policy measures, like performance standards, the amount of environmental performance improvements is dictated by the policy. With some other policy measures, like environmental taxes, the firm can choose to what extent it wishes to implement environmental performance improvements and to what extent it wishes to pay the environmental tax.

\section{Mechanisms from environmental policy to economic performance}

Figure 3 illustrates the positive and negative linkages between environmental policy and firmlevel economic performance. The figure only contains the direct linkages, excluding those that arise via changes in environmental performance levels. 
Figure 3. Direct mechanisms from environmental policy to firm-level economic performance.

\begin{tabular}{|c|c|c|c|}
\hline \multirow{8}{*}{$\begin{array}{l}\text { Environmental } \\
\text { policy }\end{array}$} & & Demand creation & \multirow{8}{*}{$\begin{array}{l}\text { Firm-level } \\
\text { economic } \\
\text { performance }\end{array}$} \\
\hline & Positive & Raising rivals' costs & \\
\hline & \multirow{6}{*}{ Negative } & Environmental quality & \\
\hline & & Demand reduction & \\
\hline & & Input prices & \\
\hline & & Transaction costs & \\
\hline & & Taxes and other payments & \\
\hline & & Productivity & \\
\hline
\end{tabular}

Three different mechanisms can be distinguished through which positive competitiveness impacts may arise for a firm from environmental policy:

- Environmental policy may create demand for the firm's output. This is the case in particular for the environmental goods and services (EGS) sector, but also for other sectors whose products or services are increasingly used as inputs by other firms that need to comply with the environmental policy.

- Environmental policy may raise rivals' costs and thus improve the relative cost position of the firm. In some cases, the policy incurs costs on competitors but not on the firm itself; consider for example carbon-based energy policies and a firm generating electricity from nonfossil sources. In some other cases, both the firm and its rivals need to incur costs to comply with the policy, but because of cost asymmetries arising e.g. from economies of scale or access to inputs, compliance is more costly for the rivals (Reinhardt, 1999).

- Environmental policy may improve environmental quality. Firms whose production is dependent on environmental quality benefit from policies that generate environmental performance improvements in other firms or elsewhere in society. Such improvements can reduce costs (for example, when input purity is improved and less water purification is thus needed in the production process) or improve the value of the product or service of the firm (for example, in tourism). In other words, environmental policy may create positive externalities (or reduce negative externalities that the firm had suffered from), thus creating economic value for the firm and enhancing the framework for investment.

Five different mechanisms can be distinguished through which negative competitiveness impacts may arise from environmental policy: 
- Environmental policy may reduce demand for the firm's output. In the case of outright bans this is obvious, but other policy measures on downstream users may also affect demand. For example, the demand of chlorine may have been affected by both the Montreal Protocol, which imposed a timeline for phasing out the production of CFCs in industrialised countries, and the U.S. Cluster Rule, which tightened restrictions on the release of chlorinated compounds to water and air by pulp and paper mills (Snyder et al., 2003).

- Environmental policy may increase input prices (for example, the price of electricity) even if the firm's own environmental performance level (for example, the use of electricity) is not changed.

- Environmental policy may impose transaction costs on the firm. Whether the transactions necessary to comply with the policy occur towards the policy maker (as with taxes and command-and-control instruments) or also towards other firms (as with emissions trading systems), costs typically arise in connection with activities such as negotiating, monitoring, measuring, and reporting.

- Environmental policy may directly impose new cost elements on a firm in the form of taxes, charges and emission permit requirements.

- Environmental policy may adversely affect productivity (in addition to the impacts of environmental performance on productivity already reviewed). It may serve as a barrier to entry and result in a lock-in of capital. Moreover, when firms are uncertain about future regulation, they may delay investment or the development of new products and technologies (Shadbegian \& Gray, 2005).

\section{Net impact of environmental policy on firm-level economic performance}

As seen above, a range of possible positive and negative competitiveness impacts of environmental policy can be identified. These impacts may arise either through induced changes in the environmental performance level of a firm (Figure 2) or from the environmental policy directly (Figure 3). Kägi et al. (2005) note that environmental policy can have various competitiveness effects that partly offset each other to produce the net impact. Accordingly, the net impact of all the resulting possible positive impacts $(5+3$ types identified in Figures 2 and 3$)$ and negative impacts $(3+5$ types identified in Figures 2 and 3) determines the overall competitiveness impact of an environmental policy measure for a firm. Importantly, the different impacts may have different time frames in materialising, wherefore the net impact may look different in the short term than in the long term.

The relationship between environmental policy and competitiveness (i.e., the net competitiveness impact of environmental policy) need not be linear across environmental performance levels. Typically, the marginal costs of further improvements increase at higher environmental performance levels (and may even be negative at very low performance levels), while the marginal revenues from customers decrease. In fact, a number of authors (Lankoski, 2000; Nehrt, 1998; Schaltegger and Figge, 2000; Schaltegger and Synnestvedt, 2002; Stanwick and Stanwick, 2000; Steger, 2006; Wagner et al., 2001, 2002; and indirectly also McWilliams and Siegel, 2001; Husted and de Jesus Salazar, 2006) have argued that the relationship between environmental performance and firm-level competitiveness takes the form of an inverted U-shaped function of environmental performance (not to be confused with the Kuznets curve that relates per capita income and pollution in an inverted U-shaped fashion). In a way, the inverted $U$ hypothesis encompasses and can be compatible with hypotheses of a negative and a positive net relationship; this is a question of the range over which the competitiveness impacts are examined. 
The net competitiveness impact of environmental policy need not be uniform across situations. Of the potential positive and negative competitiveness impacts identified above, different ones may materialise, with different intensity, in different circumstances. Hence, the net impact is case-specific and may depend on the characteristics of the firm, the environmental issue and the policy measure in question.

In the context of this case-specificity, different policy measures may produce a different bundle of individual competitiveness impacts. We have already discussed how the choice of policy measures partly determines the extent to which environmental performance improvements are generated in firms, and thus the extent of the resulting competitiveness impacts. In addition, different policy instruments may differ in terms of their demand impacts (demand creation and demand reduction), cost impacts on the firm and its rivals (transaction costs, amount of taxes and other payments, changes in productivity and in input prices, raising rivals' costs) as well as on impacts on environmental quality (see Figure 3). For example, in contrast to other environmental policy instruments, environmentally related taxes or tradable permit systems "not only make the firms pay for the measures they take to reduce their emissions, but also place a price on all remaining emissions" (OECD, 2008: 38).

An example of the firm- or industry-specific nature of the impacts is the fact that the competitiveness impacts of an environmental policy can differ depending on the structure of the industry that the firm belongs to. This is because industry structure affects the ability of firms to pass on eventual cost increases. As discussed in Smith (2003), those firms that sell a homogeneous product in a perfectly competitive market are price takers; in their case, cost increases cannot be passed on to customers in product prices but the firm is faced with reduced profits. By contrast, those firms that have some degree of market power can pass (part of) the cost increase in product prices, which reduces the competitiveness impacts. Such market power can originate from the firm selling a homogeneous product in an oligopoly or monopoly market, or from the firm selling differentiated products.

Finally, the relationship between environmental policy and competitiveness is a dynamic one, dependent on technological development and changes in market preferences. From a policy perspective, this dynamics means that policy-makers need to stay updated of changes in the relationship, but also that because the relationship is not fixed, policy-making can play a part in influencing its development.

\section{Mechanisms from economic performance to environmental policy}

Whether adverse competitiveness impacts of environmental policy are real or perceived, concerns about such impacts may affect environmental policy-making. This may result in defeating environmental policy proposals or influencing the strictness of policies and choice of policy measures in order to avoid adverse competitiveness impacts. For example, Woods (2006) found that states systematically adjusted their environmental policy enforcement behaviour in US surface mining if their enforcement stringency exceeded that of states with similar mining conditions in the region.

However, expected positive competitiveness impacts can also lead firms to lobby for stricter environmental policies. This can be the case if the firms expect the new environmental policy to create demand for their product, raise rivals' costs, or improve environmental quality in ways relevant to their production, as listed in Figure 3. For example, "it is well documented that in the 1980s, Dupont lobbied to ban CFCs and other ozone-depleting substances, because it had the leadership in the research for substitutes" (Reinhardt, 2000; ref. A mbec $\&$ Lanoie, 2008: 51). Of course, in addition to this impact on environmental policy, expected positive competitiveness impacts (such as those listed 
in Figure 2: efficiency, improved stakeholder relations, differentiation, market access, and new business) can induce improvements in the firms' environmental performance directly, without policy intervention. Firms have often been found to overcomply with environmental policies or take environmental initiatives in advance of governments to maintain or improve competitiveness.

\section{Competitiveness at sectoral and national levels}

The competitiveness impacts of environmental policy are created at the firm level, and the firmlevel impacts attract a lot of attention and influence policy consideration. However, other levels of analysis are relevant as well. Extending the understanding of the firm-level impacts to the sectoral and national levels is necessary to obtain a full picture of the competitiveness impacts of environmental policy.

At the sectoral level, the competitiveness of firms that operate within a given industry is examined from an aggregate perspective. Since firms within the same industry can differ from one another in terms of their inputs, strategies, technologies, resources, and so on, the competitiveness impacts of environmental policy can vary between different firms in a sector. If the differences between firms are significant, the various firm-level mechanisms presented above can produce for some firms a net competitiveness impact that is positive, while for some other firms this net impact can be negative. Thus, there can be both winners and losers from environmental policy in a sector. Unless the winners and losers "cancel out" each other, changes in aggregate sectoral competitiveness will result. These can have consequences for the scale of activity of the sector, and thus for the composition of the national economy.

The step from firm-level or sectoral competitiveness to national competitiveness is more complicated. In order to be competitive, that is, to be able to increase its economic standard of living, a country needs economically successful firms. A necessary but not sufficient condition for this are suitable macroeconomic conditions (the macroeconomic, political, legal, and social context and the endowments of natural resources and geographic location) as well as microeconomic conditions (the quality of the microeconomic business environment and the benefits provided by clusters of related and supporting industries). These conditions provide an opportunity for business success. How this opportunity is translated into competitiveness depends on the sophistication and capabilities of companies. (Porter et al., 2007) (See Figure 4).

Figure 4. The build-up of national competitiveness (see Porter et al., 2007)

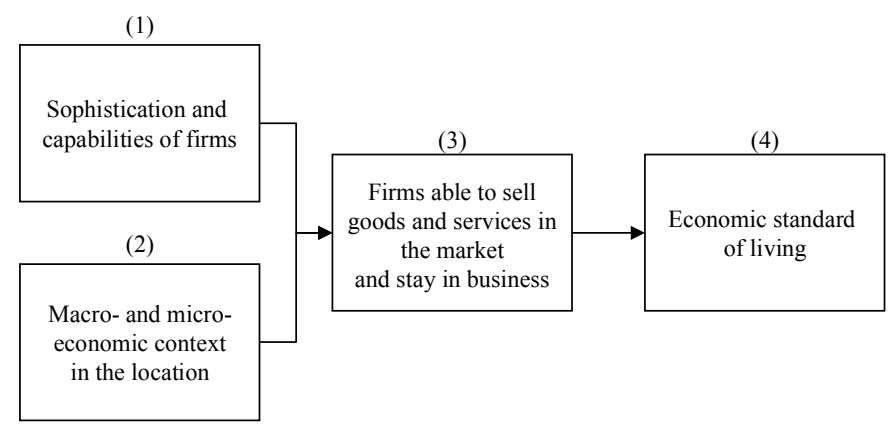


In other words, it is the combination of location characteristics and firm activities that determine firm-level and sectoral competitiveness. They also determine national competitiveness insofar as this refers to the aggregate, overall economic success of the sectors in an economy. Just as there may be winning and losing firms from an environmental policy change within a sector, there may be winning and losing sectors in the national economy. However, the expansion and contraction of individual sectors cannot be considered to simply cancel out each other; general equilibrium effects that occur though interactions between sectors (substitutes and complements) need also to be factored in the analysis.

What may confuse discussions of national competitiveness is that definitions and studies can be built around different parts of Figure 4. Some focus on the economic standard of living achieved (box 4 in Figure 4), others on the presence of firms and sectors with successful economic or trade performance (box 3), and still others on the attractiveness of the locational context provided by the national economy (box 2). While these are all interrelated, it is easy to see from Figure 4 that in particular locational attractiveness (box 2) is not directly comparable to the other approaches to national competitiveness.

Indeed, broad changes in the economy give rise to different approaches to national competitiveness. The early perception of national competitiveness related to market performance in international trade. With the freeing of capital movements, competition as location for investment gained prominence. With technological development and the importance of information as a production factor, competition for intellectual capital may be a key issue for future analyses. (Nikinmaa, 2004)

In practice, it can be difficult to reconcile results between the firm, sectoral, and national levels. Reasons for this can include the different meaning attached to the term competitiveness at different analysis levels, as well as the contrast between heterogeneous situations at the firm level and the assumptions and generalisations in sectoral or national models.

\section{Globalisation context}

Globalisation can influence the environmental behaviour and performance of firms in various ways. This is important, because as noted, policy is one among many motives for environmental performance improvements for firms, and the strength of the other motivations affects the need for environmental policies. First, globalisation can affect the targets that firms set for their environmental performance. In a globalised world economy, a large share of economic activity is in the hands of multinational enterprises (MNEs), and global outsourcing in the supply chain is also increasing. It has been argued that business considerations, such as reputation or economies of scale, may motivate MNEs and companies that outsource their activities not to exploit differences in environmental policy across jurisdictions but rather to seek common performance standards corresponding to those in their home countries from their subsidiaries and suppliers. Thus, one result of globalisation can be that environmental self-regulation is spreading through MNE structures and global supply chains. Second, globalisation can affect the ability of firms to improve their environmental performance as environmental technology, knowledge, and best practices are disseminated through trade and investment linkages.

Empirical studies have found some support for the argument that MNEs are spreading higher environmental performance standards. Ruud (2002) found that cross-border environmental management by MNE headquarters had a significant influence on the environmental performance of affiliated units in India. However, this influence did not extend beyond the affiliated MNE units to local partners, suppliers and consumers. Christmann (2004) found that MNEs in the chemical industry 
did standardise their environmental policies globally, but that they standardised different policy dimensions in response to perceived pressures from different external stakeholders. Government pressures contributed to the adoption of high internal global environmental performance standards, customer pressures to the standardisation of environmental communication, and industry pressures to the standardisation of operational environmental policies. Chudnovsky and Lopez (2003) review studies on the environmental performance of MNE affiliates and conclude that although the environmental standards, technologies and management approaches of MNE affiliates in developing countries may not equal those employed by the parent companies or by MNE affiliates in developed countries, they are nevertheless often more advanced than those adopted by local firms.

There is also empirical support for the spreading of environmental standards through global supply chains. Christmann and Taylor (2001) argued that global ties may increase self-regulation pressures on firms in low-regulation countries. Using survey data from firms in China they found that, in addition to multinational ownership, also multinational customers and exports to developed countries increased firms' self-regulation of environmental performance. Prakash and Potoski (2006) set out to investigate whether international trade encourages firms to adopt the ISO 14001 environmental management system. Using panel data from 108 countries over seven years, they found that high levels of adoption of ISO 14001 in the importing countries encouraged firms in the exporting countries to adopt this voluntary environmental program (it should be noted, though, that this is a built-in feature of the ISO 14001).

Globalisation can influence the linkages from environmental policy to competitiveness. In particular, when firm reputation is increasingly global, firms need to satisfy a wide range of global stakeholders to avoid a negative market reaction. When competition is global, both the environmental performance of a firm and the price of its product or service can be judged against global benchmarks, and customers have easy access to the products and services of non-regulated competitors.

Moreover, globalisation is a phenomenon that extends not only to economic activity but also to other domains, including to the making of environmental policy. With internationally coordinated or global environmental policies, competitiveness impacts are different from those with unilateral policy measures. For example, Cassels and Meister (2001) examined effluent control in the New Zealand dairy sector and found that whereas unilateral policy action resulted in a reduction of exports, a scenario where other principal exporters adopted a similar policy resulted in increased export competitiveness for New Zealand. Even without explicit international coordination in policy-making, it has been argued that in a globalised economy, stringent environmental requirements tend to migrate from the strict to the lenient jurisdictions, thus making eventual competitiveness gains from lenient standards only temporary. Such a "California effect" - the "ratcheting upward of regulatory standards in competing political jurisdictions" - has been identified, e.g. in the context of automobile standards (Vogel, 1995).

Globalisation can also influence the linkages from perceived competitiveness impacts to environmental policy-making. With increased competition, interest groups may feel a more urgent need to oppose any cost-increasing policy proposals. Additionally, when production is more mobile thanks to trade liberalisation and developments in computing, telecommunications, and transportation, pressure groups have more leverage on policy (Adams, 1997).

Finally, globalisation complicates the analysis of competitiveness impacts of environmental policy. When economic institutions are changing and value chains are being reassembled beyond sectoral boundaries (see Berger, 2000), and when firms are no longer contained within national territories, sectoral or national level analyses may become misleading. For example, the relocation of activities by an MNE from the home country to a host country could read as a loss of national 
competitiveness for the home country, but could at the same time also mean increased competitiveness for one of the home country firms, the MNE. In other words, with increasingly mobile capital and labour, the two-way link between competitiveness at firm level and national level is broken: if national competitiveness is lost, a firm can still relocate and do well (Nikinmaa, 2004).

\section{REVIEW OF RECENT EMPIRICAL STUDIES}

In this chapter, recent empirical research on the competitiveness impacts of environmental policies is reviewed. The literature is vast, and rather than to update the reader of the results of each empirical study since 1997, the objective is to provide an interpretation of the body of research, showing eventual developments and outlining the current state of knowledge. In addition to reviewing key ex post studies, the chapter also reviews ex ante studies on competitiveness impacts and ends with a discussion of the body of recent empirical research.

The empirical literature has tended to form certain research strains, and the literature review is organised around these existing study groups. Following the framework in the previous chapter, the review is again divided in two main parts: studies on the environmental performance competitiveness relationship and studies on the environmental policy - competitiveness relationship. Note, however, that while we can in an analytical framework separate cleanly the different avenues for the competitiveness impacts, this has not been done in the existing empirical studies. This means especially that the empirical studies on the policy - competitiveness relationship are not limited to the direct impacts of environmental policy (as in Figure 3) but also capture those impacts arising via induced changes in firms' environmental performance. Moreover, the existing empirical policy studies tend to be conducted not at the firm level but at the sectoral or national level.

\section{Studies connecting environmental performance and competitiveness}

This section reviews firm-level studies that seek to establish a connection between environmental performance and competitiveness (typically expressed as accounting or stock market performance). Studies in the first group focus on a general relationship; in other words, they address the net impact of all the individual avenues identified in the framework in Chapter 2. Studies in the second group continue to address the net impact, but in a more refined way, as they explicitly take into account potential case-specificity in the net relationship.

\section{General relationship}

Attempts to discover a general, systematic relationship between the environmental and economic performance of a firm began in the 1970s and have continued to date with increasing pace. Currently more than 100 empirical studies exist of the topic. The key methodological approaches are to correlate some measures of environmental performance with some measures of accounting performance or to measure the stock market reaction to environmental performance through event studies or portfolio comparisons. Some of the relevant firm-level competitiveness studies cover environmental performance as part of the broader topic of social performance. 
The studies have produced contradictory results. Recent studies have found evidence of both a positive relationship (e.g. Konar \& Cohen, 2001; Wahba, 2008) and a negative relationship (e.g. Wagner et al., 2002; López et al., 2007) between the environmental and economic performance of a firm. Some other studies have concluded on a neutral or non-existing relationship (e.g. Elsayed \& Paton, 2005; McWilliams \& Siegel, 2000; Murray et al., 2006).

Not surprisingly, then, the mainstream conclusion from this body of research has been that the nature of the relationship cannot be determined with certainty (e.g. Roman et al., 1999; Schaltegger \& Figge, 2000; Aragón-Correa \& Sharma, 2003; Salzmann et al., 2005; Vogel, 2005; Barnett \& Salomon, 2006; Barnett, 2007; Darnall et al., 2007; Halme \& Laurila, 2008).

Two influential reviews published in 2003, however, arrived at a positive conclusion about the relationship between corporate responsibility (including environmental responsibility) and economic performance. Margolis and Walsh (2003) classified 109 quantitative studies published during 19722002 and found that 54 studies reported a positive relationship, 7 studies reported a negative relationship, 28 studies reported non-significant relationship and 20 studies had mixed findings. They considered these results as a clear signal that "there is a positive association, and certainly very little evidence of a negative association" between responsibility and economic performance.

Orlitzky et al. (2003) opposed simple vote-counting of the different results and instead opted for a statistical meta-analysis of the literature. Their meta-analysis, which covered 52 quantitative studies published during 1972-1997, showed that "corporate virtue in the form of social responsibility and, to a lesser extent, environmental responsibility is likely to pay off" (p. 403). Thus, Orlitzky et al. rejected the mainstream view that the results are inconclusive, and concluded that we can "state with some confidence that the association between CSP [corporate social performance, including environmental performance] and lagged CFP [corporate financial performance] is not negative" (p. 424).

\section{Case-specific relationship}

The lack of conclusive findings about the relationship has led some researchers to continue the attempts to settle the issue with improved methods and data sets. However, the reaction of some other researchers has been to question the existence of one general relationship entirely and to argue that the competitiveness impacts of environmental performance are not universal but contingent. Thus, they try to identify conditions on which the relationship may depend. Theoretical and empirical research from this perspective has arisen especially during the 2000s.

Lankoski (2008a) presents a review of firm-specific and issue-specific factors that have been empirically found to moderate the firm-level relationship between social/environmental and economic performance. Some of these factors relate to the characteristics of the firm and its external environment. One such characteristics is the industry that the firm belongs to. The competitiveness impacts were more positive in high-growth industries (Russo \& Fouts, 1997) and in industries with little differentiation (Hull \& Rothenberg, 2008). Also, Goll and Rasheed (2004) found that discretionary social responsibility contributed to firm performance in environments that are dynamic and munificent.

Another characteristics is the type of reputation that the firm is targeting. From the perspective of competitiveness impacts, it is more important to avoid a negative reputation than to create a positive reputation. In other words, being environmentally irresponsible harms competitiveness but it is not clear that being environmentally responsible improves competitiveness (see e.g. Frooman, 1997; Bird et al., 2007; van der Laan et al., 2008). 
Some of the relevant firm characteristics relate to internal competencies and management practices of the firm. Organizational capabilities for stakeholder integration, higher learning and continuous innovation (Sharma \& Vredenburg, 1998), ability to integrate environmental issues in strategic planning (Judge \& Douglas, 1998), favourable organizational competence profiles (Karagozoglu \& Lindell, 2000), and ability to implement process innovations (Christmann, 2000) have all been found to increase the ability of the firm to reap positive competitiveness impacts from environmental performance improvements. Moreover, the way in which environmental management is implemented also matters: for example, King and Lenox (2002) and Wagner (2005) found that pollution prevention improved competitiveness but other ways to reduce emissions and wastes did not.

Characteristics of the environmental issue may also matter for the competitiveness impacts. To take a simple example, reducing waste may often result in improved competitiveness through savings in input costs, which is not the case for reducing noise. Literature is beginning to point to different issues having different competitiveness impacts (e.g. Hillman \& Keim, 2001; Lankoski, 2007). However, the existing studies apply rather to environmental issues vs. other dimensions of corporate responsibility than to differences between individual environmental issues. An exception is the study by Gilley et al. (2000) which found that the market reaction was more favourable towards environmental initiatives that were related to the product than to environmental initiatives related to the production process.

Further to these empirical findings, a number of firm and issue characteristics have been proposed theoretically to affect the competitiveness impacts of environmental performance improvements. These characteristics may affect the extent of cost changes relative to competitors and the ability to pass on eventual cost increases to customers. Such issue-specific characteristics include e.g. the nature of available solutions (like the possibility for process improvements vs. end-of-pipe changes); the visibility of the issue to stakeholders that depends on the immediate perceivability of the issue and on the presence of visibility champions such as vocal NGOs or labelling systems; and the extent to which the issue creates customer willingness to pay by appealing to emotions or by its ties to private benefits for the customer. Firm-specific characteristics, in turn, include e.g. the choice of alternative solutions that depends on capital intensity and sunk costs in existing production methods, investment cycles, locational constraints, and the extent of "unpicked low-hanging fruit"; the visibility of the firm that depends on location in environmental or socioeconomic terms, firm size, and nature of end product; and customer willingness to pay that depends on the customer segment and the nature of competition. (Lankoski, 2000)

\section{Studies connecting environmental policy and competitiveness}

This section reviews sectoral and national level studies trying to find a link between the strictness of environmental policies and competitiveness. Studies in the first group focus on productivity and studies in the second group focus on innovation and the development of new markets and industries. These study groups address selected individual avenues in the framework in Chapter 2, not the overall net impact. Studies in the third group focus on trade flows and studies in the fourth group focus on investment and location decisions. These study groups address the net impact on competitiveness of the various avenues identified in the analytical framework.

\section{Impacts on productivity}

There is a relatively large body of literature that seeks to establish a connection between environmental policy and productivity. This is not surprising considering the fact that for many authors, productivity is the key element in defining competitiveness (e.g. Porter et al., 2007). According to the analytical framework presented above, environmental policy could influence 
productivity both directly (freezing technology as a negative impact) and through induced environmental performance improvements (increased production costs and the more subtle ways of reducing productivity on the negative side, and improved resource efficiency on the positive side). It remains an empirical question to see whether the positive or the negative impacts dominate.

Adams (1997) summarised the then state of knowledge on environmental policy and productivity as follows: "Some research has attributed declines in productivity to the cost of complying with environmental regulation. For standard measures of productivity, this is true by definition, because an increase in inputs is recorded but the "output" generated by this input - reduced emissions - is not counted in traditional output measures. When avoided environmental damage costs are counted in the equation, a more positive view emerges of the effect of environmental regulation on productivity". Moreover, "other studies, at the plant level, have tended to find a positive relationship between environmental stringency and competitiveness as measured by productivity or profitability" (Adams, 1997).

Since 1997, a number of empirical studies on environmental policy and productivity have been published. However, the findings have been mixed: researchers have discovered a positive relationship (for example, Berman \& Bui, 2001; Alpay et al., 2002, for the Mexican case), a negative relationship (for example, Gray \& Shadbegian, 2003; Dufour et al. 1998), or no relationship (for example, Alpay et al., 2002, for the US case).

As noted, one factor in assessing the impacts of environmental policy on productivity is whether a traditional productivity measure is used or one that takes account of the environmental benefits obtained (Repetto et al., 1997). Telle \& Larsson (2007), for example, produced both a traditional Malmquist productivity index, and an environmental Malmquist productivity index where emissions were accounted for, and found that the traditional index produced more pessimistic results. However, it is unlikely that this approach could settle the debate on environmental policy and competitiveness because it blends together private and social costs and benefits of environmental policy, and the debate essentially concerns potential trade-offs between the private vs. social costs and benefits.

Lanoie et al. (2008) noted that only the contemporaneous impacts of environmental policy on productivity had been examined, which did not allow for the dynamic effects of policy to work through. To correct for this deficiency, they introduced a time lag in their regulatory variable. This had important impacts on the results: the contemporaneous impact of environmental regulation on productivity was negative, but the opposite result was observed with lagged regulatory variables.

In sum, while the earlier studies pointed towards a negative impact of environmental regulation on productivity, more recent papers have found positive results (Lanoie et al., 2008).

\section{Impacts on innovation and the development of new markets and industries}

The development of new markets and industries, and more generally, innovation, is another avenue connecting environmental policy to competitiveness that has been subjected to empirical research. The motive for these studies is that policy may trigger innovation in firms that, besides efficiency improvements, may result in product differentiation, access to new markets or the creation of new business, and that particular benefits may be available to the "first-movers" in these areas (e.g. Porter \& van der Linde, 1995).

On innovation, Adams (1997) concluded that "Many company examples show that cost-saving innovations result when a firm has to comply with a new environmental measure... It is not surprising that quality improvements or production cost reductions can result from closer attention to resource 
efficiency and "clean production" technology." While this conclusion focuses on efficiency improvements, it is positive about the potential of innovation in general.

Again, several new empirical studies connecting environmental policy to innovation have been conducted since 1997. These studies typically focus on input measures such as R\&D expenditures or output measures such as successful patent applications. According to Lanoie et al. (2008), studies have found a positive relationship between environmental policy and R\&D expenditures (e.g. Jaffe \& Palmer, 1997; Arimura et al., 2007) and between environmental policy and successful patent applications (e.g. Brunnermeier \& Cohen, 2003; Popp, 2006). Other studies, however, have found no impact (e.g. Jaffe \& Palmer, 1997 on the number of patents). For example, Gagelmann and Frondel (2005) found that the innovation effects of US emissions trading schemes (the Acid Rain Program, the Regional Clean Air Incentives Market, and the Lead Phasedown Program for automotive fuels) were initially limited because of lenient or even non-constraining targets.

Roediger-Schluga (2003) presents micro-level case evidence on the consequences that the Austrian Volatile Organic Compound (VOC) emissions standards, which were the most restrictive of their kind in the world, had on $\mathrm{R} \& \mathrm{D}$, product range, and innovation in the paints, coatings, printing inks, and adhesives industry. He found that the policy "gave rise to considerable changes in firms' product range and appear to have accelerated the rate of product innovation in the regulated industry" (p. 359). However, there was also evidence that R\&D spending to comply with the policy did displace or postpone existing R\&D projects, but it could not be ascertained whether some of these would have been more productive than the projects to develop compliant products. Additionally, the compliance efforts did give rise to ancillary benefits in the form of new knowledge and new competencies, but again it was uncertain to what extent these represented real innovations and to what extent simply technologically backward firms catching up. This shows that even if developments consistent with the hypothesis that environmental regulation stimulates innovation and the development of new products do take place, further analysis is required to ascertain that these developments indeed represent winwin outcomes.

\section{Impacts on trade flows}

An important body of empirical research on environmental policy and competitiveness consists of studies that link the stringency of environmental policies to trade flows. The thinking behind these studies is that the overall net competitiveness impacts created on individual firms by environmental policy are reflected in sectoral and national trade flows.

In 1997, the state of empirical knowledge on environmental policy and trade flows could be summarised as follows: "Most studies show insignificant relationships between stringent environmental regulations and competitiveness, in the various ways these have been measured. Some of the more recent and more focused studies have found the predicted negative effect on trade flows at a disaggregated level, but it is small, varies by industry depending on international market structure, and varies over time" (Adams, 1997).

According to the review by Copeland and Taylor (2004), however, the pre-1997 consensus that differences in the stringency of environmental policy have little or no effect on trade and investment flows was premature, as the second wave of empirical studies has produced a reversal to earlier findings. Levinson and Taylor (2008) argue that studies on the relationship between environmental policy and trade flows suffer from inadequate accounting for unobserved heterogeneity in country and sector characteristics, and from the endogeneity of pollution abatement cost measures, and that "these issues -and not the relatively small costs of pollution abatement or the Porter hypothesis - are responsible for the mixed results produced so far" (p. 224). Accounting for these econometric and data 
issues (with panel data and instruments to control for endogeneity of regulatory stringency), Levinson and Taylor found that environmental policy did have an impact on trade flows that was consistent with the pollution haven hypothesis, and that this impact was not only statistically but also economically significant. Also Ederington and Minier (2003) found a negative effect of environmental policy on trade flows when the level of environmental regulation was treated as endogenous.

Brunnermeier and Levinson (2004) conclude in their review of the literature that "the earlier consensus that regulatory differences do not matter is beginning to change" (p. 7), and that with methodological improvements, studies have found "statistically significant pollution haven effects of reasonable magnitude" (p. 6) both at the sectoral and national levels. However, it must be emphasized that the evidence "supports the existence of a pollution-haven effect only. The evidence indicates that after controlling for other factors affecting trade and investment flows, more stringent environmental policy acts as a deterrent to dirty good production. None of this work presents evidence that this deterrent effect is strong enough to be the primary determinant of the direction of trade or investment flows." (Copeland \& Taylor, 2004).

\section{Impacts on investment and location decisions}

One more body of empirical literature on environmental policy and competitiveness consists of studies that seek to link the stringency of environmental policy to foreign direct investment patterns and domestic plant location decisions. The logic behind these studies is that if environmental policy produces adverse net competitiveness impacts, firms would seek to avoid such impacts by directing their investments to or choosing their location in jurisdictions without such environmental policies.

According to Adams (1997), "neither the investment data nor the evidence on location decisions show clear evidence of industrial migration or pollution havens in response to differentials in environmental standards."

This question has continued to receive considerable empirical research attention since 1997. Some studies have reported on a negative relationship. List and Co (2000) examined state environmental regulations and foreign multinational corporations' new plant location decisions and found support for an inverse relationship between environmental stringency and the attractiveness of a location. Keller and Levinson (2002) found "robust evidence that abatement costs have had moderate deterrent effects on foreign investment". Xing and Kolstad (2002) found that the laxity of environmental regulations in a host country was a significant determinant of FDI from the US for heavily polluting industries, although not for less polluting industries. List et al. (2003) found that pollution-intensive plants were responding to environmental regulations, and Becker and Henderson (2000) found that nonattainment status of air quality regulations, which triggers specific equipment requirements, reduced plant births for polluting industries. Counterintuitively, however, the findings of Cole and Ensign (2005) demonstrated a trend of US FDI into Mexico in industries characterized as lower polluting. And, Javorcik and Wei (2004) found no support for the pollution haven hypothesis that stringent environmental standards induce relocation of firms.

In their meta-analysis of new plant location decisions, Jeppesen et al. (2002) found that study methodology was a crucial explanatory factor for the lack of robust results. Indeed, the conclusion by Brunnermeier and Levinson (2004) that with methodological improvements pollution haven effects have become visible applies not only to international trade patterns but also to plant locations and investment decisions.

Echoing the contingency approach in the firm-level studies, recent findings are pointing to heterogeneity of environmental policy impacts on industry location both spatially and across industry 
(Mulatu, 2008). Co et al. (2004) found that the effect of environmental policy on capital flows was heterogeneous across industries. Millimet and List (2004), in turn, found that the impacts of environmental policy on industry location depended crucially on observable location-specific attributes, such as level of unemployment, agglomeration externalities, and supply of skilled labour. They "suspect that once all heterogeneity is taken into account, the empirical findings will begin to match expectations" (p. 261).

Ederington et al. (2005) argued that the pollution haven effect has been difficult to detect because the most polluting sectors are often also the least footloose, that is, the least geographically mobile. This geographical immobility can be due to transportation costs, plant fixed costs, or agglomeration economics, and results in these sectors being insensitive to differences in regulatory stringency. Even if there are impacts on the more footloose sectors, aggregation over multiple sectors has served to conceal these impacts in the empirical studies.

Taylor (2004, ref. Mulatu, 2008) argued that researchers have confused a pollution haven effect (that environmental policy has an effect on trade flows and industry location at the margin) and a pollution haven hypothesis (that environmental policy predicts trade and investment patterns). In order for the pollution haven hypothesis to be true, not only does the pollution haven effect have to exist, but this effect also needs to be strong compared to other determinants of industry location. Building on this notion, Mulatu (2008) analysed empirically the weight of environmental policy vis-à-vis other determinants on industry location in Europe. Mulatu found support for a pollution haven effect but not for the pollution haven hypothesis. He concluded that "while variations in environmental stringency and pollution intensity are considerable influence on location decisions, the other traditional Heckscher-Olin factors are also strong influence individually, and jointly are likely to dominate the influence of the environmental factor."

In sum, the evidence on environmental policy and investment and location decisions remains inconclusive. According to Mulatu (2008), reviews of the empirical literature have concluded that the evidence is mixed or that the correlations are weak. With methodological improvements, researchers have been able to uncover a pollution haven effect, but this effect is heterogeneous, and likely to be overshadowed by other determinants of industry location.

\section{Forecasts and simulations of competitiveness impacts of environmental policies}

In addition to the various types of ex post studies reviewed above that measure the realized impacts of environmental policy on competitiveness, this relationship has also been approached through ex ante studies that attempt to forecast the competitiveness impacts of a specific environmental policy. Such approaches include industry surveys of compliance costs as well as various simulation models. Typically, these studies cover only a limited subset of the individual avenues identified in the framework in Chapter 2, with an emphasis on the most easily quantifiable avenues such as direct production costs.

One application area of ex ante studies with significant recent activity is the assessment of potential competitiveness impacts of climate policies. In particular, the potential competitiveness impacts of the European Union emissions trading scheme (ETS) have been examined. Oberndorfer and Rennings (2007) review ten such studies that were carried out between the years 2000 and 2006 with computable general equilibrium models, partial models and macroeconomic models. Based on their review, Oberndorfer and Rennings conclude that "the fears of the majority of sectors concerned about strong negative competitiveness impacts of the EU ETS are not justified". This is the conclusion in spite of the fact that none of the reviewed studies incorporate potential innovation effects. Oberndorfer and Rennings further note that the selected reference level is crucial for the results. 
Models against a business as usual scenario tend to find modest negative competitiveness impacts; however, the aluminium sector is an exception with its significant loss of competitiveness. Models against an alternative scenario of fulfilling Kyoto obligations without emissions trading tend to find positive competitiveness impacts.

In a similar vein, Graichen et al. (2008) argue that in Germany, only a small number of sectors (basic iron and steel, fertilizers and nitrogen compounds, paper and paperboard, aluminium and aluminium products, and certain basic inorganic chemicals).may be exposed to competitiveness distortions due to the EU emissions trading scheme. This is because in order for the competitiveness impacts to materialise a sector needs both to incur important cost increases from the policy and be exposed to international trade.

OECD (2008) examined the extent of carbon leakage in post-2012 international climate policy options through simulations. Carbon leakage could occur through the competitiveness channel and the fossil fuel price channel. The study concludes that "preliminary analysis suggests that fears of carbon leakage - i.e. that emission cuts in a limited number of participating countries might be partly offset by increases elsewhere - may be overstated. Unless only a few countries take action against climate change, for instance the European Union acting alone, leakage rates are found to be almost negligible, below $2 \%$ for instance in the case of Annex I countries cutting their emissions by $50 \%$ by $2050 . "$ (p. 5)

Another recent application example for an ex ante assessment of competitiveness impacts of environmental policies is the 2007 implementation of the EU chemicals regulation REACH (the Registration, Evaluation and Authorisation of Chemicals). According to Ackerman et al. (2008), the industries that are affected by REACH "expressed grave concern in advance, suggesting that costs might be enormous. However, after years of research and debate, there are no credible, published estimates of REACH compliance costs that are large enough to justify these concerns" (p. 26). Ackerman et al. note that the low costs of REACH compliance are in line with research findings on other regulations.

The ex ante studies rely on estimates of compliance costs, but it is uncertain how reliable such cost estimates can be. According to Sherrington and Moran (2007), "reviews of a number of environmental and industrial regulations have shown that ex ante costs tend to exceed the ex post (or outturn) costs". For example, this was the finding of Harrington et al. (2000) who compared ex ante and ex post costs of 25 individual regulations in the US. Haq et al. (2001) compared the predicted costs and envisaged strategies presented by industry during the negotiation phase, and the actual costs incurred and strategies adopted in the implementation phase, for five environmental regulations (including e.g. the EC Directive on Vehicle Emission Standards and the United States Clean Air Act). They concluded that "from the analysis of the case studies examined, it can be inferred that industry's actual costs for implementing environmental regulations were lower than its predictions of these costs during the negotiations." On the other hand, Morgenstern et al. (2001) argue that "recent literature supports the idea that reported expenditures probably understate the actual burden". Studying a large panel of plant-level data, however, they find no significant deviation in either direction in three manufacturing industries, and statistically significant overstatement of costs in one industry.

\section{Discussion of recent empirical research}

\section{Summary of empirical results}

In total, the earlier conclusion has been that "there is no clear empirical evidence that high, or even relatively high, environmental standards have a systematic negative impact on competitiveness at the macroeconomic or microeconomic level." (Adams, 1997). A substantial amount of new research 
has been conducted since that conclusion, and a number of individual studies have uncovered positive, negative, or neutral competitiveness impacts resulting from environmental policy. The overall results still remain indecisive.

There are several reasons why it can be considered that the vast empirical literature has so far failed to settle the issue:

- The results are not compatible with each other. Different studies yield contradictory findings, and the communication between different strands of research could be stronger.

- The results are not compatible with theoretical predictions. The theoretical argument that environmental policy hurts competitiveness has not been substantiated empirically. However, as the argument is theoretically persuasive within mainstream economics, researchers keep on attempting to uncover the predicted impacts.

- The results are not compatible with policy-making practice. Even if the adverse competitiveness impacts have failed to be corroborated, this has not changed the political economy of environmental policy-making: the pollution haven hypothesis is widely believed (Levinson \& Taylor, 2008), and firms typically oppose environmental policy proposals by appealing to a loss of competitiveness.

Those researchers who think that some conclusions can be drawn from the mixed body of evidence connecting environmental performance to competitiveness at the firm level tend to argue that the relationship is slightly positive, or at least not negative. On the other hand, those researchers who think that some pattern does emerge from the recent sectoral and national level studies connecting environmental policy to competitiveness expressed as trade flows and location decisions tend to interpret this relationship as negative. If these conclusions are accurate, there can be two simultaneously valid explanations for such results:

- One explanation is that environmental policies produce adverse competitiveness impacts (e.g. because they are inefficient or inflexible or have high transaction costs) that are avoided when firms improve their environmental performance voluntarily. This would call for an improved design of environmental policies.

- Another explanation is that firms undertake initiatives that are in their private commercial interest, but environmental policy targets those environmental issues and measures where the benefits are primarily external to the firms and that would therefore not be addressed without the policy (Johnstone, 2007). Indeed, Darnall et al. (2007) found that "if there are "winwins" they are not induced through regulatory stringency" (Johnstone, 2007, 264).

\section{Data and methodological explanations for the lack of conclusive results}

Although the general methodological sophistication has been increasing, a great number of data and methodological concerns can still be identified to explain the inability of empirical research to conclusively determine the relationship between environmental policy and competitiveness. Brunnermeier and Levinson (2004) identify measurement of dependent variable, measurement of regulatory stringency, choice of control variables, geographical unit of analysis, level of industry aggregation, the use of cross-section vs. panel data, and endogeneity correction as sources for incomparable results. Various reviews have identified altogether almost 50 different methodological or measurement problems in the body of research on the firm-level relationship between corporate responsibility (including environmental responsibility) and competitiveness (Vogel, 2005). 
The definition and measurement of key variables, such as the stringency and form of environmental policy, or competitiveness at the different levels, can be problematic. For example, if environmental policy is empirically measured through abatement costs, as is often the case, this already contains a built-in assumption that policy stringency and abatement costs are monotonous transformations of one another. Or, while it is known that not only the stringency but also the policy design and implementation details influence the competitiveness impacts of environmental policy, this is rarely captured in the studies.

There are many reasons why currently available empirical data, no matter how well collected, may not be able to answer the fundamental question of the relationship between environmental policy and competitiveness. First, the policies of which we have empirical data may not have been "welldesigned" in Porter's meaning, so they may not provide a test of the Porter hypothesis that welldesigned environmental policies can promote competitiveness. Second, because full internalisation of environmental costs has not, generally speaking, taken place, we cannot have empirical data of how this would impact competitiveness (Lankoski, 2008b). Third, there is a "chilling effect" at work in environmental policy: when significant adverse competitiveness impacts are to be expected, they are usually not allowed to materialise fully, but exceptions and compensating mechanisms are designed to mitigate the adverse impacts (see also the discussion in Chapter 4). Thus, eventual adverse competitiveness impacts do not show in the empirical data. (Esty, 1996).

The simulation models used to assess competitiveness impacts suffer from a missing variable problem. We have seen that there are a great number of potential channels from environmental policy to competitiveness, but the models can only take into account impacts that have been specified by the model builder. For example, the models do not usually take into account innovation offsets.

The assessment of abatement costs is also difficult, and the costs may be under- or overstated. Stakeholders may have a strategic interest to inflate or play down cost estimates. In addition, there can be uncounted costs: for example, Joshi et al. (2001) examined 55 steel mills and found that a $\$ 1$ increase in the visible cost of environmental regulation was associated with an increase of $\$ 9-\$ 10$ in hidden costs. There can also be additional savings that result from innovation offsets, unanticipated technological development, unanticipated market reaction, or unmeasured complementarities between environmental activities and the non-environmental production (Bailey et al., 2002; Morgenstern et al., 2001; Sherrington \& Moran, 2007). Finally, early estimates of abatement costs may represent overestimates simply because over the negotiation process of the regulation, requirements are often modified to reduce competitiveness concerns (Ackerman et al., 2008).

\section{Substantive explanations for the lack of conclusive results}

In addition to data and methodological explanations, there are also possible substantive explanations for the inability of empirical research to detect a systematic and consistent relationship between environmental policy and competitiveness. One such explanation commonly offered is that environmental costs constitute such a small share of total costs, and differences in policy stringency between trading partners have been so small, that any important competitiveness impacts simply do not exist (see e.g. Adams, 1997).

Further, firms may react to competitive pressures in different ways than assumed by the data collection effort. For example, firms may outsource certain production phases rather than relocate the whole operation. Jenkins et al. (2002, ref. Pieters, 2008) found evidence of off-shoring the dirtiest parts of the value chain, and Jeppesen and Folmer (2001) found that plant closing was a more likely response than relocation. Or, firms may not take action immediately but only when a suitable opportunity arises within their investment cycle. 
Another possibility is that there is some underlying relationship between environmental policy and competitiveness, but this relationship is masked by other, opposing drivers. In particular, endowments with capital, skilled labour, or natural resources (the factor endowments hypothesis) may serve to neutralise the impacts of environmental policies (the pollution haven hypothesis) (Pieters, 2008). Thus, in real-life competition, the competitiveness impacts do not materialise.

The view is gaining foothold that the relationship is not universal but contingent: the magnitude and even the direction of competitiveness impacts may differ between different firms and industries, types of policies, or environmental issues, e.g. due to market structure and the nature of competition and the resulting ability of firms to pass on cost increases. Hence, the relationship is easily lost in aggregation. Rather than finding a one-size-fits-all answer, the task is to understand the nature of the impacts in specific circumstances.

From a policy perspective, the different competitiveness implications of different types of policy measures are of key importance. For example, Frondel et al. (2007) found that direct regulations such as technology standards encouraged end-of-pipe abatement, but input taxes promoted changes in production processes, which are expected to be more benign to competitiveness. Moreover, not only the resulting environmental policy but also the political process through which the policy is arrived at may play a role as the process may be used as an opportunity to build trust, initiate partnerships, and share information.

Finally, it should be noted that no matter how reliably we can gauge the relationship between environmental policy and competitiveness in some situation, the extent to which the findings are applicable to some other, future situation is limited. If the relationship follows a dynamic, casespecific inverted $\mathrm{U}$, as we have argued, extrapolating findings across different firms, issues, strictness levels or time periods is problematic. (Lankoski, 2008a)

\section{REVIEW OF PROS AND CONS OF MEASURES PROPOSED TO ADDRESS ADVERSE COMPETITIVENESS IMPACTS OF ENVIRONMENTAL POLICY}

Next, we turn to considering the other side of the two-way linkages between environmental policy and competitiveness: the impacts that competitiveness concerns may have on environmental policy-making. We focus on one issue. Because of competitiveness concerns, various measures have been proposed to accompany environmental policies with the aim of mitigating eventual adverse competitiveness impacts. In the discussion of existing empirical research we noted that such measures are one reason for the fact that major adverse competitiveness impacts from environmental policies have been difficult to demonstrate empirically. This chapter will discuss what kinds of measures are generally available for addressing adverse competitiveness impacts, what considerations need to be taken into account when proposing such measures, and what the literature has to say about the pros and cons of the measures. While this chapter focuses on competitiveness impacts vis-à-vis international competitors, it should be borne in mind that competitiveness impacts of environmental policy can also arise in relation to domestic competitors (for example, substitutes from different industries) that are non-regulated or that experience the impacts of the regulation differently. 


\section{Types of measures}

Following Reinaud (2008), the possible measures to address adverse competitiveness impacts of environmental policies can be divided in three groups: measures to soften competitiveness impacts in regulated countries, measures to promote environmental action in non-regulated countries, and measures to adjust the impacts of environmental policies at the border. Within each group, different measures can be identified. Note that what measures are available in each situation depends on the form of the original environmental policy instrument. For example, free initial allocation can only be used in connection with tradable emission permits, and recycling revenues can only be used in connection with revenue-generating policy instruments such as environmental taxes or auctioned permits.

\section{Measures to soften the impacts of environmental policies in regulated countries}

This group of measures attempts to directly prevent cost increases that may arise in the regulated country as a result of an environmental policy. When the cost shock of the environmental policy is small to start with, competitiveness impacts towards international, non-regulated rivals are minimized. A number of measures have been proposed or applied in this context, including:

- modifying the environmental obligations: less stringent objectives, partial exemptions

- modifying the allocation mode of allowances: total or partial free initial allocation of emission permits

- offering flexibility in the regulatory system: access to offsets, credits, banking, borrowing

- recycling revenues from the environmental policy to affected sectors: direct financial compensation, reduction of indirect costs

- $\quad$ direct support through targeted subsidies

\section{Measures to promote environmental action in non-regulated countries}

This group of measures attempts to encourage international rivals in non-regulated countries to undertake similar environmental action than that prescribed by the environmental policy. Hence, even if the environmental policy results in cost increases in the regulated country, relative competitive positions are not changed since international rivals will incur similar costs. Relevant measures include (see e.g. van Asselt \& Biermann, 2007):

- broadening the geographic coverage of regulations

- international sectoral agreements

- bilateral or small-party agreements with some countries

- adjusting the Generalised System of Preferences of the European Union

\section{Measures to adjust the impacts of environmental policies at the border}

This group of measures does not attempt to prevent cost differentials from arising between regulated and non-regulated rivals, but instead deals with their international trade impacts at the 
border. When exports are recompensed for the incremental costs, and imports are restricted, the competitive playing field remains unchanged both in the regulated and unregulated countries, although the level of environmental performance is higher in the regulated countries. Measures to recompense exports include border cost adjustment for exports. Measures that would be theoretically available for restricting imports include the following (see e.g. van Asselt \& Biermann, 2007):

- $\quad$ border cost adjustments for imports

- $\quad$ import quotas

- technical regulations and standards that specify environmental performance requirements and apply also to imported products

- counter-measures through a WTO challenge

- $\quad$ punitive tariffs, taxes or permit requirements

- restricting trade with non-parties to a multilateral environmental agreement

- $\quad$ influencing consumer behaviour, e.g. through labelling

\section{Assessment criteria}

Several perspectives - economic, environmental, legal, and political - need to be employed in order to be able to effectively examine the pros and cons of the various measures to address adverse competitiveness impacts of environmental policies. Determining a set of definitive assessment criteria is complicated, but some potentially relevant considerations can be identified.

From an economic perspective, a well-designed measure ought to be able to mitigate competitiveness concerns in a fashion that does not create additional economic burdens elsewhere. Relevant considerations may include:

- $\quad$ ability to mitigate competitiveness concerns

- impact on economic growth overall (both in the country applying the measure and in other countries)

- administrative practicability and transaction costs

- $\quad$ ability to promote innovation

From an environmental perspective, a well-designed measure ought not to hurt the environmental objectives while addressing the competitiveness concerns. Relevant considerations may include:

- ability to uphold environmental objectives set in the original policy

- ability to maintain the price signal in the regulated economy (e.g. for carbon in the case of climate policies)

- in the case of carbon policies, ability to prevent carbon leakage 
From a legal perspective, a well-designed measure ought to be compatible with existing legislation. Relevant considerations may include:

- compatibility with WTO rules (e.g. non-discrimination between like products, the principle of international cooperation)

- compatibility with domestic and other applicable (e.g. the EU) legislation

- compatibility with international environmental commitments

From a political perspective, a well-designed measure ought to be feasible and acceptable. Relevant considerations may include (see e.g. van Asselt \& Biermann, 2007):

- compatibility with general political objectives of the implementing country

- not harming political relationships with other governments

- $\quad$ ability to take into account questions of equity and fairness (e.g. common but differentiated responsibilities for environmental problems)

\section{Review of pros and cons}

This chapter shares insights from recent OECD and IEA work on measures to address the adverse impacts of environmental policy on competitiveness. After reviewing some general studies, the chapter presents studies on climate change policies as an illustrative example because this is a domain where competitiveness issues have had a strong impact on policy discussions. Questions of measures to address adverse competitiveness impacts arise also in the context of other environmental policy issues, and the chapter thus also includes some results from studies examining other environmental policies.

\section{General studies}

OECD (2008) discusses in general terms the pros and cons of various measures to address competitiveness impacts of environmental policy measures. A key point with all measures is to maintain an incentive for pollution abatement. Also, announcing environmental policy reforms early and phasing them in gradually is recommended as this can give affected polluters sufficient time to adjust to the new situation. Specific considerations with regard to particular mitigating measures are as follows:

- (Partial) recycling of environmental tax revenues back to the most affected polluters can be used to limit the competitiveness impacts. However, this forgoes the opportunity to use the revenues from environmental taxes to reduce other, distortionary taxes, and tends to reduce the environmental benefits of the tax.

- Border tax adjustments are sometimes feasible, but their full environmental and economic implications should be carefully considered before adoption. In particular, administrative costs and compatibility with international trade disciplines require attention.

- Applying reduced tax rates for the most affected sectors or firms does maintain some incentive to abate emissions, even if the incentive is reduced, and this option is therefore better than a full exemption from an environmental tax. 
- With a permit trading system, free initial allocation of emission permits or recycling the revenues from auctioned permits is able to maintain the incentive to abate.

- Seeking to involve other countries in the policy reform under consideration can also limit competitiveness impacts. However, if the environmental externality in question is essentially domestic in character, flexible policy responses could be more appropriate than harmonised action.

Smith (2003) focused on environmental taxes. On possible measures to address their competitiveness impacts the study arrived at the following conclusions:

- Revenue recycling may substantially reduce the competitiveness impacts of an environmental tax, although the changes in the pattern of taxation can have asymmetric effects for individual firms within a sector. However, this measure may also reduce the amount of pollution abatement achieved, especially when the main way to reduce pollution is to reduce output. Further, it may give distortionary incentives for firms to behave in ways that maximise their entitlement to recycled revenues.

- Border tax adjustments (BTAs), especially those that target processes and production methods, may entail significant legal impediments. In addition, there are a number of important economic problems involved. First, BTAs erode the incentives for pollution abatement, particularly in firms that are the most active in export markets. Second, if BTAs are limited to trade with countries that do not pursue equivalent environmental policies, there would be considerable difficulties in judging what level and forms of environmental policy can be considered "equivalent". Third, defining the appropriate BTA rate would be hard, unless the environmental tax was levied as a percentage share of the value of the traded product.

\section{Studies on climate policies}

Reinaud (2008) examined against a selection of economic and environmental criteria measures that have been proposed or discussed in current legislation to mitigate competitiveness impacts of $\mathrm{CO}_{2}$ emissions trading schemes. The findings with regard to the pros and cons of these measures were:

- Free initial allocation of emission permits under an absolute cap may may reduce the loss of competitiveness (and compensate for stranded assets) depending on the cap. However, it is difficult to identify vulnerable sectors, and if the allocation is too generous and if companies can pass through this cost, the measure risks conferring windfall gains on some companies. Futher, governments would miss the opportunity to auction allowances and raise revenues that could help alleviate other costs to the economy.

- Free output-based allocation of emission permits, too, may reduce the competitiveness impacts depending on the baseline. Problems include difficulty in identifying vulnerable sectors and level of efforts requested, and in monitoring production inputs. Moreover, the measure would entail higher $\mathrm{CO}_{2}$ prices for the same reductions, and the cost of delivering emissions reductions is borne by other sectors of the economy. The measure also limits the $\mathrm{CO}_{2}$ price signal in product prices, hence undermining the economic effectiveness of the emissions trading scheme as a tool to internalise climate change costs and limiting product substitution towards lower- $\mathrm{CO}_{2}$ intensive products. 
- Financial compensation for loss of competitiveness lessens the competitiveness impacts of climate policy costs, but it has a straight cost for the rest of the economy and may be considered State Aid in the EU.

- Border cost adjustments participate in levelling the $\mathrm{CO}_{2}$ playing field and, if accompanied by auctioned allowances, could allow the $\mathrm{CO}_{2}$ price signal to feed in to domestic product prices. However, the compatibility of the measure with WTO rules is uncertain. Also, if imports need to purchase emissions on the carbon market, this would increase $\mathrm{CO}_{2}$ prices, worsening the competitiveness of exports and triggering higher indirect costs. Further problems with this measure include difficulty in measuring and monitoring the embedded carbon content for specific products, complexity in developing administrative procedures for assigning process emissions to specific products, and possible gaming strategies from firms seeking to bypass the adjustment scheme.

- Sectoral agreements with crediting could represent an opportunity for a developing country to engage in greenhouse gas mitigation activities, with the prospect of receiving greenhouse gas credits for achieved reductions, and broaden the environmental integrity of the international framework. If a sectoral agreement takes the form of national sectoral binding targets in major economies, this could potentially address leakage. In the case of sectoral $\mathrm{CDM}$, a stringent baseline for crediting would limit the subsidy effect to competitors. However, establishing a proper metric to assess genuine sector-wide reduction efforts can be technically difficult. And, if permanent, financial revenues from credits and other forms of assistance could enhance the competitive position of participants, hence further distorting the playing field.

Reinaud (2008) notes that each of the measures has its merits and demerits, and how these materialise depends on the detailed design and implementation of the measures (e.g., is free initial allocation for existing or also for new facilities; is border cost adjustment for imports or also for exports) and on the specific characteristics of the sectors where the measure is implemented (e.g., is the sector electric-intensive or process emission intensive; is the sector able to pass on costs to customers). Different mitigating measures may be called for in different situations. There are also some general considerations for well-designed mitigating measures: they should be based on the establishment of a counterfactual scenario to justify where measures are needed; they should be flexible and transitional, to ensure a smooth transition towards a low-carbon economy while avoiding a commitment to ongoing assistance; and they should be such that they do not undermine a broader international climate agreement in the future but instead encourage participation in global greenhouse gas mitigation.

Burniaux et al. (2008) examine various measures that have been discussed in the context of addressing the competitiveness concerns related to post-2012 climate policies. One such measure is the partial exemption of industries, greenhouse gases, or countries from emission reduction requirements. The simulations suggest that all these measures increase significantly the costs of achieving emission reduction targets. For example, if the target is to achieve a $550 \mathrm{ppm} \mathrm{CO}_{2}$ equivalent concentration in 2050, exempting energy-intensive industries would increase the costs by over a half, exempting other greenhouse gases than $\mathrm{CO}_{2}$ would almost double the costs, and exempting non-Annex I countries would make the achievement of the target (in fact, all targets below $750 \mathrm{ppm}$ ) virtually out of reach.

Another measure analysed by the study is border cost adjustments, or countervailing tariffs. The analysis shows that this measure is able to reduce some of the competitiveness and carbon leakage effects. However, a number of problems relate to border cost adjustments: 
- They are a meaningful option only if the coalition of acting countries is very small, typically much smaller than Annex I. For example, a countervailing tariff would reduce leakage rate from $20 \%$ to $6 \%$ in a scenario where EU were to cut its emissions by $50 \%$ by 2050 , but the leakage rate would only fall from $9 \%$ to $5 \%$ in a scenario where all Annex I countries were to take similar action.

- They may not reduce the competitiveness and output losses incurred by energy-intensive industries in participating countries. This is because they increase the cost of the imported inputs used by energy-intensive industries, and because the non-energy inputs of energyintensive industries would be subject to a carbon price but countervailing tariffs are unlikely to be applied to the non-energy inputs used by the foreign competitors.

- They entail costs for both participating and non-participating countries. For example, if Annex I countries were to cut their emissions unilaterally by $50 \%$ by 2050 , a countervailing tariff would achieve an additional world emissions reduction of less than $1 \%$ of projected 2050 world emissions at an additional cost of about 1\% of world GDP.

- They could involve potentially large administrative costs and run the risk of trade retaliation.

Stringent international sectoral agreements, e.g. sectoral cap-and-trade schemes in energyintensive industries (like aluminium, cement, or steel) and in transnational sectors such as international shipping and air transport, are considered a more promising option. Such agreements would allow larger emission cuts to be achieved at a lower overall cost, but they can have large impacts on the cross-country distribution of costs. These impacts depend on the details of sectoral and economy-wide trading schemes and whether these schemes are integrated.

\section{Studies on other policies}

OECD (2006) analysed empirical country case studies on the implementation of environmental policies with potential negative impacts on competitiveness. The case studies included the proposed industrial energy consumption tax in France, the United Kingdom Climate Change Levy, the Norvegian aviation fuel tax, the MINAS nutrient accounting system in the Netherlands, the Swiss heavy goods vehicle road use fee, and the Irish plastic bag tax. Thus, while the first three cases still deal with climate change policies, the latter three expand the perspective to other environmental policies. Messages that arose from the case studies include the following:

- Different mitigating measures, with different effects on both environment and competitiveness, are available.

- There is often a trade-off between transaction costs and political acceptance, so that mechanisms introduced to address competitiveness concerns result in an increase in the administrative costs. For example, this was the case with the MINAS in the Netherlands.

- In order to make the owners of the firms equally well-off as before, relatively modest compensation mechanisms can often suffice, depending on how insulated the domestic market is from international competition. Indeed, the risk of overcompensation is serious and needs to be taken into account.

The study by OECD (2006) also reviewed some lessons learned from the US experience of border tax adjustments in connection with Superfund legislation and the phase-out of ozone-depleting chemicals. One lesson relates to the amount of the countervailing tax. On the one hand, border tax 
adjustments should be avoided where the tax is a trivial proportion of the product price; otherwise there is a risk of creating substantial administrative burden with very little environmental benefit. On the other hand, if the tax reaches a significant proportion of the product price, this can exacerbate problems of tax evasion, including illegal trade. Another lesson relates to the fact that if manufacturers are required to provide commercially sensitive information on the materials and processes involved in manufacturing a product for the purposes of the border tax adjustment system, this may produce competitiveness concerns of its own.

\section{Discussion of analysis of pros and cons}

One message that arises from the discussion of pros and cons of the mitigating measures in the literature is that there are no categorical answers. All measures to mitigate adverse competitiveness impacts have positive and negative features, and it depends on the specifics of the environmental problem and the original environmental policy, as well as on the detailed design and implementation of the mitigating measure, how the balance between the pros and cons is struck. This means that the application of mitigating measures requires careful analysis in each situation.

From the above it also follows that results from the discussion undertaken in the context of climate policies may not be directly transferable to other environmental policies. Whilst much of recent work on mitigating measures focuses on climate policies (and hence on original environmental policy measures such as emissions trading schemes and $\mathrm{CO}_{2}$ taxes), calls for addressing adverse competitiveness impacts arise also with other environmental policies. Thus, the discussion could be broadened to cover other environmental issues and other types of original environmental policy measures.

\section{LESSONS LEARNT AND WAYS FORWARD}

Over the past ten years, the debate on environmental policy and competitiveness has slowly developed towards a more fine-grained understanding and analysis of this heterogeneous relationship. One important message that is arising is that, in order to understand the relationship between environmental policy and competitiveness, it is necessary to fully recognise a multinational or global perspective to the issues along with the national perspective.

Another important message that has been learnt is that the impacts can be highly case-specific. First, the competitiveness impacts depend on the type of environmental policy measure adopted and the details of its implementation. Thus, we cannot determine with certainty the relationship between "environmental policy in general" and competitiveness. Instead, a more focused or segmented approach to environmental policies is needed to effectively aid policy making.

Second, the competitiveness impacts depend on firm and sector characteristics. One key characteristics in this context is the structure of the industry in question. However, in addition to industry structure, there are also several other characteristics to be considered, relating for instance to the nature of products, production technologies, or customer segments. Hence, we can expect environmental policy to have different competitiveness impacts on different economic actors. 
Third, the competitiveness impacts may depend on the environmental domain. This is an emerging perspective of which little empirical analysis exists as yet. It has long been recognised that the policy-making problematique is different for different environmental issues (depending, for example, on whether the issue is local, regional or global, or whether the pollution originates from point or non-point sources), but that the competitiveness impacts may also be different is newer.

The exact competitiveness impacts of environmental policy are determined by all these types of contingencies simultaneously. Thus, we can distinguish between three levels of detail in the analysis of competitiveness impacts. At the most general level, the question to be examined is the relationship between environmental policy and competitiveness. As we have seen, there are no unconditional answers to this question. At an intermediate level of detail, what is examined are the competitiveness impacts per policy measure, per industry, or per environmental issue. Examining this question can be expected to produce clearer policy messages. At the most detailed level, the question is about how a specific policy measure targeting a specific environmental issue affects some specific firms or industries. This is the analysis level that can produce the most definitive answers. Which analysis level to choose depends on the objectives of the study to be conducted as well as on practical considerations.

\section{Policy implications in different situations}

The case-specific competitiveness impacts of environmental policy can lead to three different types of situations, and a number of policy implications arise for these situations. The policy implications presented here are all compatible with those by presented by Adams (1997) in the previous stock-taking report.

Situations where environmental policy leads to positive competitiveness impacts (so-called winwin situations) do exist. However, it is unclear how widespread such win-win situations are and how significant the positive competitiveness impacts can be. In any case, not all situations are win-win situations. Clear policy messages arise with regard to win-win situations:

- Environmental policy should be instituted for environmental reasons and not in order to pursue win-win situations.

- Nevertheless, policy should strive to be win-win-compatible. This speaks in favour of policies that provide incentives to innovation, are stable and predictable, make use of suitable transition periods, focus on end results rather than means, and use economic policy instruments (Porter \& van der Linde, 1995).

- Any win-win opportunities that exist should be identified and exploited by firms; policy can play a role in supporting firms' awareness of win-win possibilities and their capacity to implement win-win solutions.

There can also be situations where unjustified or exaggerated concerns about negative competitiveness impacts prevail (false trade-off situations). Such is the case, for example, when analysis of the competitiveness impacts focuses on cost increases only and ignores possibilities for market benefits and cost savings, or when a static analysis fails to account for dynamic effects such as innovation and technological development and thus leads to an overestimation of costs. On the other hand, there can also be overly positive expectations about the win-win potential of an environmental policy measure (false win-win situations), for example if the particular characteristics of the policy measure, the sector, and the environmental issue are not recognized. The recommendation in both cases is to obtain better information of the actual competitiveness impacts: 
- When considering the economic impacts, all the different positive and negative channels connecting environmental policy to competitiveness should be duly accounted for, even if the impacts are hard to measure or quantify.

- The impacts should be analysed with a sufficient level of detail so that the situation-specific impacts can be assessed.

Finally, situations remain where environmental policy will result in negative competitiveness impacts and there is thus a trade-off between environmental and economic objectives. Again, it is not clear how widespread trade-off situations are, and how important the adverse impacts can be. Tradeoff situations are the most challenging situations for policy-making, but there are clear policy messages also for these situations:

- It is necessary for an effective environmental policy to have competitiveness impacts in the sense that sustainable production will become more competitive and unsustainable production less competitive.

- It is exactly in the trade-off situations that environmental policy is most needed to achieve the environmental objectives; where win-win opportunities are present, more emphasis can be put on voluntary approaches by industry.

- Environmental policy development in trade-off situations requires that the environmental benefits obtained are weighed against the adverse economic consequences. This is done at the level of the whole society. Because of different preferences, the weighing may result in different outcomes in different societies or at different time periods. The weighing becomes more complicated if the spatial or temporal dispersion of the environmental benefits and of the adverse economic consequences differ from each other.

- Even when implementing the environmental policy is clearly in the overall interest of society despite the adverse competitiveness impacts, the costs and benefits of the policy are unlikely to be equally shared among societal actors. While some win, individual firms or industries may stand to lose. Policy design should make sure that the adverse competitiveness impacts are not unnecessarily large, for example by paying attention to predictability, transition periods, and transaction costs. Specific measures to support the losers in their adjustment can also be developed.

- Sometimes measures to mitigate the adverse competitiveness impacts of an environmental policy, such as those discussed in Chapter 4, are necessary to achieve political support for the policy. In those instances, the planned measures should be carefully analysed from several angles to ensure that they do not inadvertently hurt the efficiency and effectiveness of the original policy.

\section{Conclusions for further work}

Conceptual and empirical analysis indicates that both the competitiveness effects of environmental policies and the appropriateness of various measures to address those competitiveness effects are highly case-specific and depend on the firm or industry, the environmental issue, and the policy measure in question. This perspective has arisen strongly in recent years. Thus, rather than from very aggregated and general questions, robust and useful results may be obtained from smaller and more fine-grained questions. This is a direction that further work could fruitfully take. 
The identification of competitiveness effects of environmental policies needs to take account of the specific characteristics of the affected firms and industries. At the same time, however, policy development needs to be based on the overall societal perspective and not on the fates of individual firms or sectors, which means that aggregation is also necessary. Combining and balancing the disaggregated and aggregated analyses thus presents a challenge.

In this context, it would be useful if the "vast, but compartmentalised" (Pieters, 2008) literature on the relationship between environmental policy and competitiveness were better integrated. In particular, there are two broad bodies of literature (reviewed in chapters 3.1 and 3.2) that essentially address the same problematique at different analysis levels but lack exchange with each other.

It is an important but analytically neglected point that the characteristics of various environmental issues may have a bearing on the competitiveness impacts of environmental policies. Identifying the essential determining characteristics of environmental issues from the perspective of the environmental policy - competitiveness relationship would be needed. Similarly, the consideration of the justification for various measures to address competitiveness concerns can also be different for different environmental issues. For example, with a global environmental issue with potential for freeriding and leakage, the case for such measures may be stronger than with local environmental issues.

Much of recent analytical activity is focusing on climate change, but climate change is in many respects different from several other environmental issues as an environmental, economic, and political phenomenon. Engaging in corresponding work on other environmental policies than those related to climate change would thus be welcome. 


\section{REFERENCES}

Ackerman, F., Stanton, E. A., Roach, B. \& Andersson, A-S. 2008. Implications of REACH for developing countries. European Environment, 18: 16-29.

Adams, J. 1997. Environmental policy and competitiveness in a globalised economy: Conceptual issues and a review of the empirical evidence. In: Globalisation and environment: Preliminary perspectives. Paris: OECD.

Alpay, E., Buccola, S. \& Kerkvliet, J. 2002. Productivity growth and environmental regulation in Mexican and U.S. food manufacturing. American Journal of Agricultural Economics, 84(4): 887-901.

Ambec, S. \& Lanoie, P. 2008. Does it pay to be green? A systematic overview. Academy of Management Perspectives, November, 45-62.

Aragón-Correa J, Sharma S. 2003. A contingent resource-based view of proactive corporate environmental strategy. Academy of Management Review, 28: 71-88.

Arimura, T., Hibiki, A. \& Johnstone, N. 2007. An empirical study of environmental R\&D: What encourages facilities to be environmentally-innovative? In: Johnstone, N. (ed.). Environmental policy and corporate behaviour. Cheltenham: Edward Elgar.

Bailey, P. D., Haq, G \& Gouldson, A. 2002. Mind the gap! Comparing ex ante and ex post assessments of the costs of complying with environmental regulation. European Environment, 12: $245-256$.

Barla, P. 2007. ISO 14001 certification and environmental performance in Quebec's pulp and paper industry. Journal of Environmental Economics and Management, 53(3): 291-306.

Barnett, M. L. 2007. Stakeholder influence capacity and the variability of financial returns to corporate social responsibility. Academy of Management Review, 32(3): 794-816.

Barnett, M. L. \& Salomon, R. M. 2006. Beyond dichotomy: The curvilinear relationship between social performance and financial performance. Strategic Management Journal, 27, 1101-1122.

Becker, R. \& Henderson, V. 2000. Effects of air quality regulations on polluting industries. Journal of Political Economy, 108(2): 379-421.

Berger, S. 2000. Globalization and politics. Annual Review of Political Science, 3: 43-62.

Berman, E. \& Bui, L. T. M. 2001. Environmental regulation and productivity: Evidence from oil refineries. The Review of Economics and Statistics, 83(3): 498-510. 
Bird, R., Hall, A. D., Momentè, F. \& Reggiani, F. 2007. What corporate social responsibility activities are valued by the market? Journal of Business Ethics, 76: 189-206.

Brunnermeier, S. B., \& Cohen, M. A. 2003. Determinants of environmental innovation in US manufacturing industries. Journal of Environmental Economics and Management, 45: 278-293.

Brunnermeier, S. B. \& Levinson, A. 2004. Examining the evidence on environmental regulations and industry location. The Journal of Environment \& Development, 13(6): 6-41.

Burniaux, J. M., Château, J., Duval, R. \& Jamet, S. 2008. The economics of climate change mitigation: Policies and options for the future. OECD Economics Working Paper 658. Paris: OECD.

Cassels, S. M. \& Meister, A. D. 2001. Cost and trade impacts of environmental regulations: Effluent control and the New Zealand dairy sector. The Australian Journal of Agricultural and Resource Economics, 45(2): 257-274.

Christmann, P. 2000. Effects of "best practices" of environmental management on cost advantage: The role of complementary assets. Academy of Management Journal, 43(4): 663-680.

Christmann, P. 2004. Multinational companies and the natural environment: Determinants of global environmental policy standardization. Academy of Management Journal, 47(5): 747-760.

Christmann, P. \& Taylor, G. 2001. Globalization and the environment: Determinants of firm selfregulation in China. Journal of International Business Studies, 32(3): 439-458.

Chudnovsky, D. \& Lopez, A. 2003. Diffusion of environmentally friendly technologies by multinational corporations in developing countries. International Journal of Technology Management and Sustainable Development, 2(1): 5-18.

Co, C. Y., List, J. A. \& Qui, L. D. 2004. Intellectual property rights, environmental regulations, and foreign direct investment. Land Economics, 80(2): 153-173.

Cole, E. T. \& Ensign, P. C. 2005. An examination of US FDI into Mexico and its relation to NAFTA: Understanding the effects of environmental regulation and the factor endowments that affect the location decision. The International Trade Journal, 19(1): 1-30.

Copeland, B. R. \& Taylor, M. S. 2004. Trade, growth, and the environment. Journal of Economic Literature, 42: 7-71.

Darnall, N., Jolley, G. J. \& Ytterhus, B. 2007. Understanding the relationship between a facility's environmental and financial performance. In: Johnstone, N. (ed). Environmental policy and corporate behaviour. Cheltenham: Edward Elgar.

DeCanio, S. J. 2008. Book review: Environmental policy and corporate behavior. Ecological Economics, 67(2): 342-343.

Dufour, C., Lanoie, P. \& Patry, M. 1998. Regulation and productivity. Journal of Productivity Analysis, 9: 233-247. 
Ederington, J., Levinson, A. \& Minier, J. 2005. Footloose and pollution-free. The review of Economics and Statistics, 87(1): 92-99.

Ederington, J. \& Minier, J. 2003. Is environmental policy a secondary trade barrier? An empirical analysis. Canadian Journal of Economics, 36(1): 137-154.

Elsayed, K. \& Paton, D. 2005. The impact of environmental performance on firm performance: Static and dynamic panel data evidence. Structural Change \& Economic Dynamics, 16(3): 395-412.

Esty, D. 1996. Environmental regulation and competitiveness. Paper presented at the Asia Conference on Trade and the Environment, organised by the National University of Singapore and the Global Environment and Trade Study, June 27-28, Singapore.

Frondel, M., Horbach, J. \& Rennings, K. 2007. End-of-pipe or cleaner production? An empirical comparison of environmental innovation decisions across OECD countries. In: Johnstone, N. (ed.). Environmental policy and corporate behaviour. Cheltenham: Edward Elgar.

Frooman, J. 1997. Socially irresponsible and illegal behavior and shareholder wealth: A meta-analysis of event studies. Business \& Society, 36(3): 221-249.

Gagelmann, F. \& Frondel, M. 2005. The impact of emission trading on innovation - science fiction or reality? European Environment, 15: 203 - 211.

Gilley, K. M.,Worrell, D. L.,Davidson,W. N.\&El-Jelly,A. 2000. Corporate environmental initiatives and anticipated firm performance: The differential effects of process-driven versus productdriven greening initiatives. Journal of Management, 26(6): 1199-1216.

Goll, I. \& Rasheed, A. A. 2004. The moderating effect of environmental munificence and dynamism on the relationship between discretionary social responsibility and firm performance. Journal of Business Ethics, 49: 41-54.

Graichen, V., Schumacher, K., Matthes, F. C., Mohr, L., Duscha, V., Schleich, J. \& Diekmann, J. 2008. Impacts of the EU emissions trading scheme on the industrial competitiveness in Germany. Umweltbundesamt Research Report 370741501.

Gray, W. B. \& Shadbegian, R. J. 2003. Plant vintage, technology, and environmental regulation. Journal of Environmental Economics and Management, 46: 384-402.

Halme, M. \& Laurila, J. 2008. Philanthropy, integration or innovation? Exploring the financial and societal outcomes of different types of corporate responsibility. Journal of Business Ethics, forthcoming. DOI: 10.1007/s10551-008-9712-5.

Haq, G., Bailey, P. D., Chadwick, M. J., Forrester, J., Kuylenstierna, J., Leach, G., Villagrasa, D., Fergusson, M., Skinner, I. \& Obethur, S. 2001. Determining the costs to industry of environmental regulation. European Environment, 11: 125-139.

Harrington, W., Morgenstern, R. D. \& Nelson, P. 2000. On the accuracy of regulatory cost estimates. Journal of Policy Analysis and Management, 19(2): 297-322. 
Henriques, I. \& Sadorsky, P. 2007. Environmental management systems and practices: An international perspective. In: Johnstone, N. (ed.). Environmental policy and corporate behaviour. Cheltenham: Edward Elgar.

Hilliard, R. 2004. Conflicting views: Neoclassical, porterian and evolutionary approaches to the analysis of the environmental regulation of industrial activity. Journal of Economic Issues, 38(2): 509-517.

Hillman, A. J. \& Keim, G. D. 2001. Shareholder value, stakeholder management, and social issues: What's the bottom line? Strategic Management Journal, 22: 125-139.

Hull, C. E. \& Rothenberg, S. 2008. Firm performance: The interactions of corporate social performance with innovation and industry differentiation. Strategic Management Journal, 29: 781-789.

Husted B.W. \& de Jesus Salazar, J. 2006. Taking Friedman seriously: Maximizing profits and social performance. Journal of Management Studies, 43(1): 75-91.

Jaffe, A., Peterson, S., Portney, P., \& Stavins, R. 1995. Environmental regulation and the competitiveness of U.S. manufacturing: What does the evidence tell us? Journal of Economic Literature, 33: 132-163.

Jaffe, A. B. \& Palmer, K. 1997. Environmental regulation and innovation: A panel data study. Review of Economics and Statistics, 79(4): 610-619.

Javorcik, B. S. \& Wei, S-J. 2004. Pollution havens and foreign direct investment: Dirty secret or popular myth? Contributions to Economic Analysis \& Policy, 3(2): 1-32.

Jenkins, R., Barton, J., Bartzokas, A., Hesselberg, J. \& Knutsen, H. M. 2002. Environmental regulation in the new global economy: The impact on industry and competitiveness. Cheltenham: Edward Elgar.

Jeppesen, T. \& Folmer, H. 2001. The confusing relationship between environmental policy and location behaviour of firms: A methodological review of selected case studies. Annals of Regional Science, 35: 523-546.

Jeppesen, T., List, J. A. \& Folmer, H. 2002. Environmental regulations and new plant location decisions: Evidence from a meta-analysis. Journal of Regional Science, 42(1): 19-49.

Johnstone, N. 2007. Environmental policy and corporate behaviour: Policy conclusions. In: Johnstone, N. (ed.). Environmental policy and corporate behaviour. Cheltenham: Edward Elgar.

Johnstone, N., Glachant, M., Serravalle, C., Riedinger, N. \& Scapecchi, P. 2007a. 'Many a slip 'twixt the cup and the lip': Direct and indirect public policy incentives to improve corporate environmental performance. In: Johnstone, N. (ed.). Environmental policy and corporate behaviour. Cheltenham: Edward Elgar.

Johnstone, N., Serravalle, C., Scapecchi, P., \& Labonne, J. 2007b. Public environmental policy and corporate behaviour: Project background, overview of the data and summary results. In: Johnstone, N. (ed.). Environmental policy and corporate behaviour. Cheltenham: Edward Elgar. 
Joshi, S., Krishnan, R. \& Lave, L. 2001. Estimating the hidden costs of environmental regulation. The Accounting Review, 76(2): 171-198.

Judge, W. Q.\&Douglas, T. J. 1998. Performance implications of incorporating natural environmental issues into the strategic planning process: An empirical assessment. Journal of Management Studies, 35(2): 241-262.

Karagozoglu, N. \& Lindell, M. 2000. Environmental management: Testing the win-win model. Journal of Environmental Planning and Management, 43(6): 817-829.

Keller, W. \& Levinson, A. 2002. Pollution abatement costs and foreign direct investment inflows to U.S. states. The Review of Economics and Statistics, 84(4): 691-703.

King, A. \& Lenox, M. 2002. Exploring the locus of profitable pollution reduction. Management Science, 48(2): 289-299.

Konar, S. \& Cohen, M. A. 2001. Does the market value environmental performance? Review of Economics and Statistics, 83, 281-289.

Krugman, P. 1994. Competitiveness: A dangerous obsession. Foreign Affairs, 73: 28-44.

Kägi, W., Siegrist, S. \& Schäfli, M. 2005. Wettbewerb und Umweltpolitik in einer globalisierten Wirtschaft. Umwelt-Materialien 199. Bern: Bundesamt für Umwelt, Wald und Landschaft.

Lankoski L. 2000. Determinants of environmental profit: An analysis of the firm-level relationship between environmental performance and economic performance. Helsinki University of Technology, Institute of Strategy and International Business, Doctoral Dissertations 2000/1.

Lankoski, L. 2007. Differential economic impacts of corporate responsibility issues. Business \& Society, in press.

Lankoski, L. 2008a. Responsibility and the "bottom line": A literature review of the effects of corporate responsibility on firm-level economic performance (In Finnish). Publications of the Ministry of Employment and the Economy 28.

Lankoski, L. 2008b. Corporate responsibility activities and economic performance: A theory of why and how they are connected. Business Strategy and the Environment, 17: 536-547.

Lanoie, P., Patry, M. \& Lajeunesse, R. 2008. Environmental regulation and productivity: Testing the Porter hypothesis. Journal of Productivity Analysis, 30: 121-128.

Lanoie, P. \& Tanguay, G. 2000. Factors leading to green profitability: Ten case studies. Greener Management International, 31: 39-50.

Levinson, A. \& Taylor, M. S. 2008. Unmasking the pollution haven effect. International Economic Review, 49(1): 223-254.

List, J. A. \& Co, C. Y. 2000. The effects of environmental regulations on foreign direct investment. Journal of Environmental Economics and Management, 40: 1-20. 
List, J. A., Millimet, D. L., Fredriksson, P. G. \& McHone, W. W. 2003. Effects of environmental regulations on manufacturing plant births: Evidence from a propensity score matching estimator. The Review of Economics and Statistics, 85(4): 944-952.

López, M. V., Garcia, A. \& Rodriguez, L. 2007. Sustainable development and corporate performance: A study based on the Dow Jones Sustainability Index. Journal of Business Ethics, 75: 285-300.

Lorenz, T., Lebreton, B. \& Van Wassenhove, L. N. 2008. The REACH directive and its impact on the European chemical industry: A critical review. INSEAD Faculty and Research Working Papers 2008/53/ISIC. Fontainebleau: INSEAD.

Margolis, J. D. \& Walsh, J. P. 2003. Misery loves companies: Rethinking social initiatives by business. Administrative Science Quarterly, 48, 268-305.

McWilliams, A. \& Siegel, D. 2000. Corporate social responsibility and financial performance: Correlation or misspecification? Strategic Management Journal, 21: 603-609.

McWilliams A, Siegel D. 2001. Corporate social responsibility: A theory of the firm perspective. Academy of Management Review, 26: 117-127.

Millimet, D. L. \& List, J. A. 2004. The case of the missing pollution haven hypothesis. Journal of Regulatory Economics, 26(3): 239-262.

Morgenstern, R. D., Pizer, W. A. \& Shih, J. 2001. The cost of environmental protection. The Review of Economics and Statistics, 83(4): 732-738.

Mulatu, A. 2008. Weighing the relative importance of environmental regulation for industry location. University of Manchester, Economics Discussion Paper Series EDP-0803.

Murray, A., Sinclair, D., Power, D. \& Gray, R. 2006. Do financial markets care about social and environmental disclosure? Further evidence and exploration from the UK. Accounting, Auditing \& Accountability Journal, 19(2): 228-255.

Nehrt C. 1998. Maintainability of first mover advantages when environmental regulations differ between countries. Academy of Management Review, 23: 77-97.

Nikinmaa, T. 2004. Environmental protection and competitiveness. Helsinki: The Research Institute of the Finnish Economy. (In Finnish)

Oberndofer, U. \& Rennings, K. 2007. Costs and competitiveness effects of the European Union emissions trading scheme. European Environment, 17: 1-17.

OECD. 2006. The political economy of environmentally related taxes. Paris: OECD.

OECD. 2008. An OECD framework for effective and efficient environmental policies. Paris: OECD.

Orlitzky, M., Schmidt, F. L. \& Rynes, S. L. 2003. Corporate social and financial performance: A meta-analysis. Organization Studies, 24: 403-441.

Pieters, J. 2008. Globalisation, environment and competitiveness. Report prepared for the OECD. 
Popp, D. 2006. International innovation and diffusion of air pollution control technologies: The effects of $\mathrm{NO}_{\mathrm{x}}$ and $\mathrm{SO}_{2}$ regulation in the US, Japan, and Germany. Journal of Environmental Economics and Management, 51(1): 46-71.

Porter, M. E., Ketels, C. \& Delgado, M. 2007. The microeconomic foundations of prosperity: Findings from the Business Competitiveness Index. In: The global competitiveness report 2007-2008. World Economic Forum.

Porter M, van der Linde C. 1995. Toward a new conception of the environment-competitiveness relationship. Journal of Economic Perspectives, 9(4): 97-118.

Prakash, A. \& Potoski, M. 2006. Racing to the bottom? Trade, environmental governance, and ISO 14001. American Journal of Political Science, 50(2): 350-364.

Reinaud, J. 2008. Issues behind competitiveness and carbon leakage: Focus on heavy industry. IEA Information Paper. Paris: OECD/IEA.

Reinhardt, F. L. 1999. Market failure and the environmental policies of firms: Economic rationales for "beyond compliance" behaviour. Journal of Industrial Ecology, 3(1): 9-21.

Reinhardt, F. L. 2000. Down to earth: Applying business principles to environmental management. Cambridge: Harvard Business School Press.

Repetto, R., Rothman, D., Faeth, P. \& Austin, D. 1997. Has environmental protection really reduced productivity growth? Challenge, January-February: 46-57.

Roediger-Schluga, T. 2003. Some micro-evidence on the "Porter hypothesis" from Austrian VOC emission standards. Growth and Change, 34(3): 359-379.

Roman, R. M., Hayibor, S. \& Agle, B. R. 1999. The relationship between social and financial performance: Repainting a portrait. Business \& Society, 38: 109-125.

Russo, M. V.\&Fouts, P. A. 1997. A resource-based perspective on corporate environmental performance and profitability. Academy of Management Journal, 40(3): 534-559.

Ruud, A. 2002. Environmental management of transnational corporations in India - Are TNCs creating islands of environmental excellence in a sea of dirt? Business Strategy and the Environment, 11: 103-118.

Salzmann, O., Ionescu-Somers, A. \& Steger, U. 2005. The business case for corporate sustainability: Literature review and research options. European Management Journal, 23(1): 27-36.

Schaltegger S, Figge F. 2000. Environmental shareholder value: Economic success with corporate environmental management. Eco-Management and Auditing, 7: 29-42.

Schaltegger, S. \& Synnestvedt, T. 2002. The link between "green" and economic success: Environmental management as the crucial trigger between environmental and economic performance. Journal of Environmental Management, 65: 339-346.

Shadbegian, R. J. \& Gray, W. B. 2005. Pollution abatement expenditures and plant-level productivity: A production function approach. Ecological Economics, 54: 196-208. 
Sharma, S. \& Vredenburg, H. 1998. Proactive corporate environmental strategy and the development of competitively valuable organizational capabilities. Strategic Management Journal, 19: 729753.

Sherrington, C. \& Moran, D. 2007. The accuracy of regulatory cost estimates: A study of the London congestion charging scheme. European Environment, 17: 106-123.

Smith, S. 2003. Environmental taxes and competitiveness: An overview of issues, policy options, and research needs. COM/ENV/EPOC/DAFFE/CFA(2001)90/FINAL. Paris: OECD.

Snyder, L. D., Miller, N. H. \& Stavins, R. N. 2003. The effects of environmental regulation on technology diffusion: The case of chlorine manufacturing. AEA Papers and Proceedings, 93(2): 431-435.

Stanwick S, Stanwick P. 2000. The relationship between environmental disclosures and financial performance: An empirical study of U.S. firms. Eco-Management and Auditing, 7: 155-164.

Steger, U. 2006. Building a business case for corporate sustainability. In S. Schaltegger \& W. Wagner (Eds.), Managing the business case for sustainability: The integration of social, environmental and economic performance. Sheffield, UK: Greenleaf.

Taylor, M. S. 2004. Unbundling the pollution haven hypothesis. Advances in Economic Analysis \& Policy, 4(2): Article 8.

Telle, K. \& Larsson, J. 2007. Do environmental regulations hamper productivity growth? How accounting for improvements of plants' environmental performance can change the conclusion. Ecological Economics, 61: 438-445.

Van Asselt, H. \& Biermann, F. 2007. European emissions trading and the international competitiveness of energy-intensive industries: a legal and political evaluation of possible supporting measures. Energy Policy, 35: 497-506.

Van der Laan, G., Van Ees, H. \& Van Witteloostuijn, A. 2008. Corporate social and financial performance: An extended stakeholder theory, and empirical test with accounting measures. Journal of Business Ethics, 79: 299-310.

Vogel, D. 1995. Trading up: Consumer and environmental regulation in a global economy. Cambridge, MA: Harvard University Press.

Vogel, D. J. 2005. Is there a market for virtue? The business case for corporate social responsibility. California Management Review, 47(4): 19-45.

Wagner, M. 2005. Sustainability and competitive advantage: Empirical evidence on the influence of strategic choices between environmental management approaches. Environmental Quality Management, Spring: 31-48.

Wagner, M., Schaltegger, S. \& Wehrmeyer, W. 2001. The relationship between the environmental and economic performance of firms: What does theory propose and what does empirical evidence tell us? Greener Management International, 34: 95-108. 
Wagner, M., Van Phu, N., Azomahou, T. \& Wehrmeyer, W. 2002. The relationship between the environmental and economic performance of firms: An empirical analysis of the European paper industry. Corporate Social Responsibility and Environmental Management, 9: 133-146.

Wahba, H. 2008. Does the market value corporate environmental responsibility? An empirical examination. Corporate Social Responsibility and Environmental Management, 15(2): 89-99.

Woods, N. D. 2006. Interstate competition and environmental regulation: A test of the race-to-thebottom thesis. Social Science Quarterly, 87(1): 174-189.

Xing, Y. \& Kolstad, C. 2002. Do lax environmental regulations attract foreign investment? Environmental and Resource Economics, 21(1): 1-22. 